\title{
R.H. BARNES
}

\section{Hongi Hinga and its implications A war of colonial consolidation in the Timor Residency in 1904}

Around 1910, the Netherlands Indies established its boundaries as they were to remain until, depending on how one chooses to view the matter, 1942 or 1949. In order to achieve this end, the government adopted an aggressive policy of forcibly subjecting those principalities in the Indies which previously it had indulged with considerable, if inconsistent, neglect. ${ }^{1}$ A repeated complaint of authorities in the outer regions in the decades leading up to this transition had been the persistence of small wars and gratuitous acts of violence perpetrated largely, but not exclusively, by local rulers (see for example Riedel 1885). In the Timor Residency, the government determined to meet these disruptions with resolute measures. Among the first such interventions was an armed force dispatched to suppress a rebellion ${ }^{2}$ against the Raja of Adonara in a battle which has become known locally as the Hongi Hinga. ${ }^{3}$

On 1 August 1904 a force consisting of 30 European and 30 native troops under Sea Lieutenant L. van den Borg, which had been landed 30 July at Sagu on the north coast of Adonara, marched in the company of the Raja

1 For a brief general discussion of the events and policy shifts that brought about the new colonial state, see Ricklefs 1981:125-39. For a more detailed discussion with emphasis on the Timor Residency and especially Flores and adjacent islands, see Dietrich 1989. For a pungent statement of views, see Resink 1968.

2 See Dietrich 1989:62-3 for observations on the vocabulary by which the Netherlands Indies authorities shifted the definition of the nature of local conflicts and the steps they were taking against them, for example 'liberation', 'rounding off the state', 'excursion', 'expedition', 'rebel', 'rebellion', and more of the same.

3 Hongi originally referred to 'a heavily armed fleet of proas at the time of the Dutch East Indian Company (1602-1800) used during a project to destroy nutmeg [clove] trees' (SchmidgallTellings and Stevens 1981:115) or an indigenous Moluccan war fleet, consisting of a number of armed prahu undertaking expeditions of piracy and murder, also applied to expeditions undertaken by the governors of the Moluccas in the time of the Company (Gonggrijp 1934:438).

R.H. BARNES is Professor of Social Anthropology at the University of Oxford, where he also obtained his DPhil degree. A specialist on eastern Indonesia, he is the author of Kédang; A study of the collective thought of an eastern Indonesian people, Oxford: Clarendon, 1974, and Sea hunters of Indonesia; Fishers and weavers of Lamalera, Oxford: Clarendon, 1996. Professor Barnes may be reached at the Institute of Social and Cultural Anthropology, University of Oxford, 51 Banbury Road, Oxford OX2 6PE, England. 


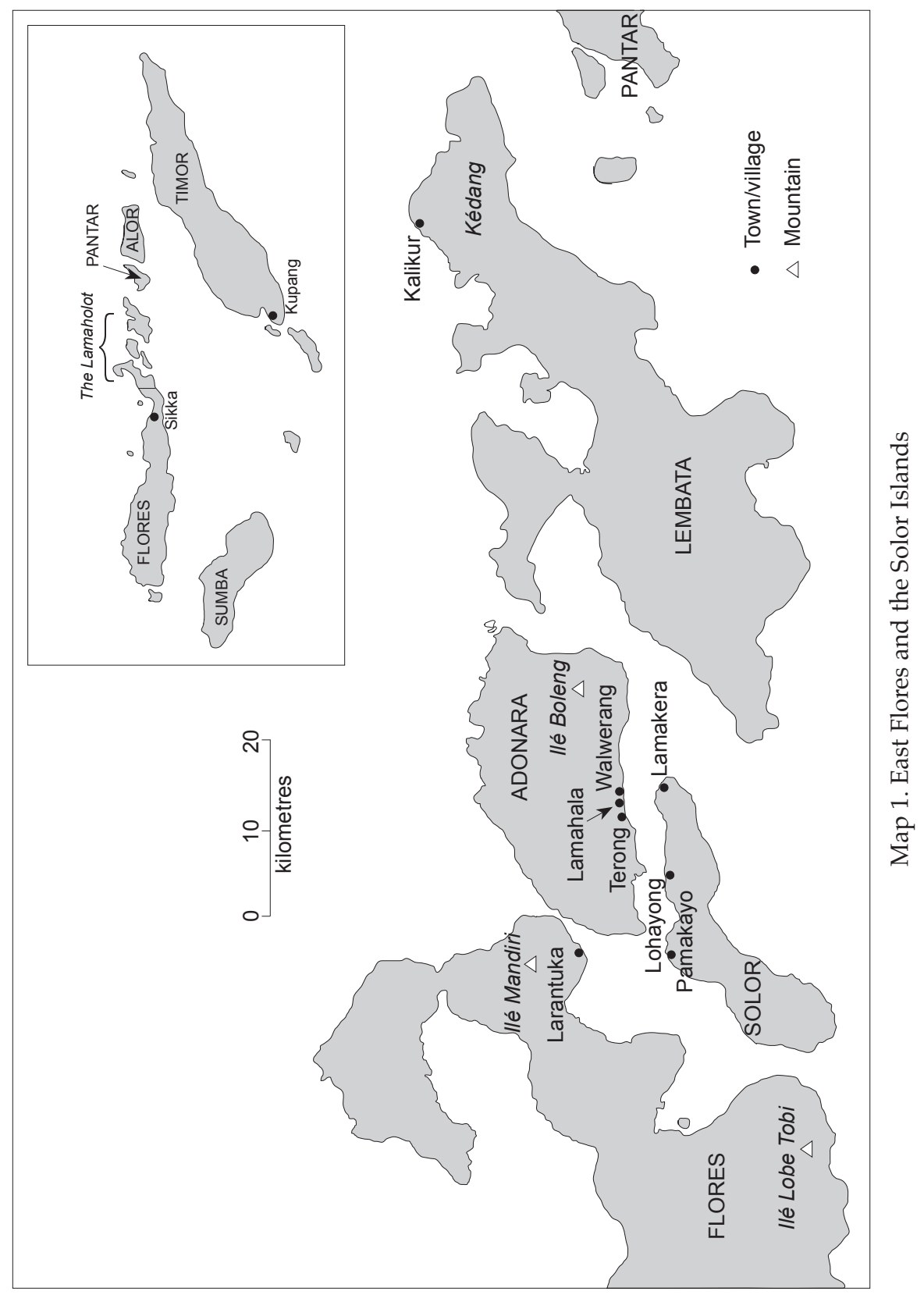


of Adonara, together with auxiliary troops from Adonara and Lembata, to Hinga, which with associated villages had been in a state of open rebellion against the Raja of Adonara for some years. Hinga they found deserted, so after putting it to flame they returned to bivouac at Lamabunga, a section of which was also in rebellion and allied to Hinga. During the night, news reached them that Hinga, Lamabunga, Witihama ${ }^{4}$ and Muda had taken positions in a sort of fortification near the village of Muda. On 2 August, the Raja of Adonara expressed the opinion that as long as the population which had fled Hinga could find shelter in neighbouring villages, they would not submit. Therefore, the next morning, 3 August, the force marched to Muda which it attacked. During this attack Van den Borg and two of the native troops were shot and killed. However, the attack was successful and the defenders fled, leaving behind many dead and wounded. Three men and forty-three women were killed. After plundering and setting fire to Muda with the help of friendly inhabitants of Witihama who had rushed to the scene, the force returned to Sagu, leaving behind the native troops and carrying their dead with them for burial in Sagu. ${ }^{5}$

The events that led to this action had already brought about the arrest and eventual exile of the Raja of Larantuka, Flores, and the arrest and eventual sentencing to hard labour of the Kakang 6 of nearby Kiwangona. In the place

4 Local village organization needs some explication. In some cases a single settlement was able to expand by establishing satellite settlements around it. In time what began as a hamlet or village name became attached to an entire region, losing its reference to a specific settlement. This process appears to have been what happened to Witihama, although the original site which bore the name Witihama is now called Oringbele. Similar processes may account for the fact that Lewohoko (Lewoko) in West Adonara and Lewoingu (Lewingu) in eastern Flores are the names of regions rather than villages. In recent decades, the regional government began to refer to Hinga, Witihama, Kiwangona, and so on as complexes and later to recognize them as sub-districts (perwakilan kecamatan) comprised of desa or official villages. In 2001, Lamabunga, Witihama, Hinga, Kiwangona and others became officially recognized districts (kecamatan). Hinga, Lamabunga and Kiwangona, however, refer both to settlements and regions, often simultaneously, in the material covered in this article. Muda and Dua are now and have always been merely hamlets.

$5 \quad$ Heckler to governor-general, 12-8-1904, 'Kort verslag omtrent den toestand en de voornaamste gebeurtenissen in de Residentie Timor en Onderhoorigheden over de maand Juli 1904', pp. 13-8, in: Nationaal Archief (NA), The Hague, Inventaris Ministerie van Koloniën 1900-1963 (Min. Kol.), Openbaar verbaal 1901-1952, nummer toegang 2.10.36.04, inventarisnummer (inv.) 373, Verbaal (Vb.) 25-1-1907, no. 52; Hagenaar, 'Beknopte gegevens betreffende het patrouillegebied van het detachement te Larantoeka omvattende Larantoeka, Maoemere, Adonara, Soloren en Lomblen', pp. 113-4, in: NA, Inventaris Memories van Overgave 1849-1962 (MvO), 2.10.39, Collectie Koninklijk Instituut voor de Tropen (KIT), 1300; J.J. Rambonnet to Commandant der Zeemacht te Batavia, 7-8-1904, pp. 4-8, in: NA, Min. Kol., 2.10.36.04, inv. 373, Vb. 21-4-1906, no. 55.; B. 1905:979-81; Onlusten 1907:371-3; Kalesar n.d.a:40-2, n.d.b:27-8. For a photograph of the monument to Van den Borg erected in Sagu by his companions, see Barnes 2001:304.

6 The heads of the various districts which together made up the realm of the Raja of Larantuka were designated kakang. The comparable title for the realm of the Raja of Adonara is 


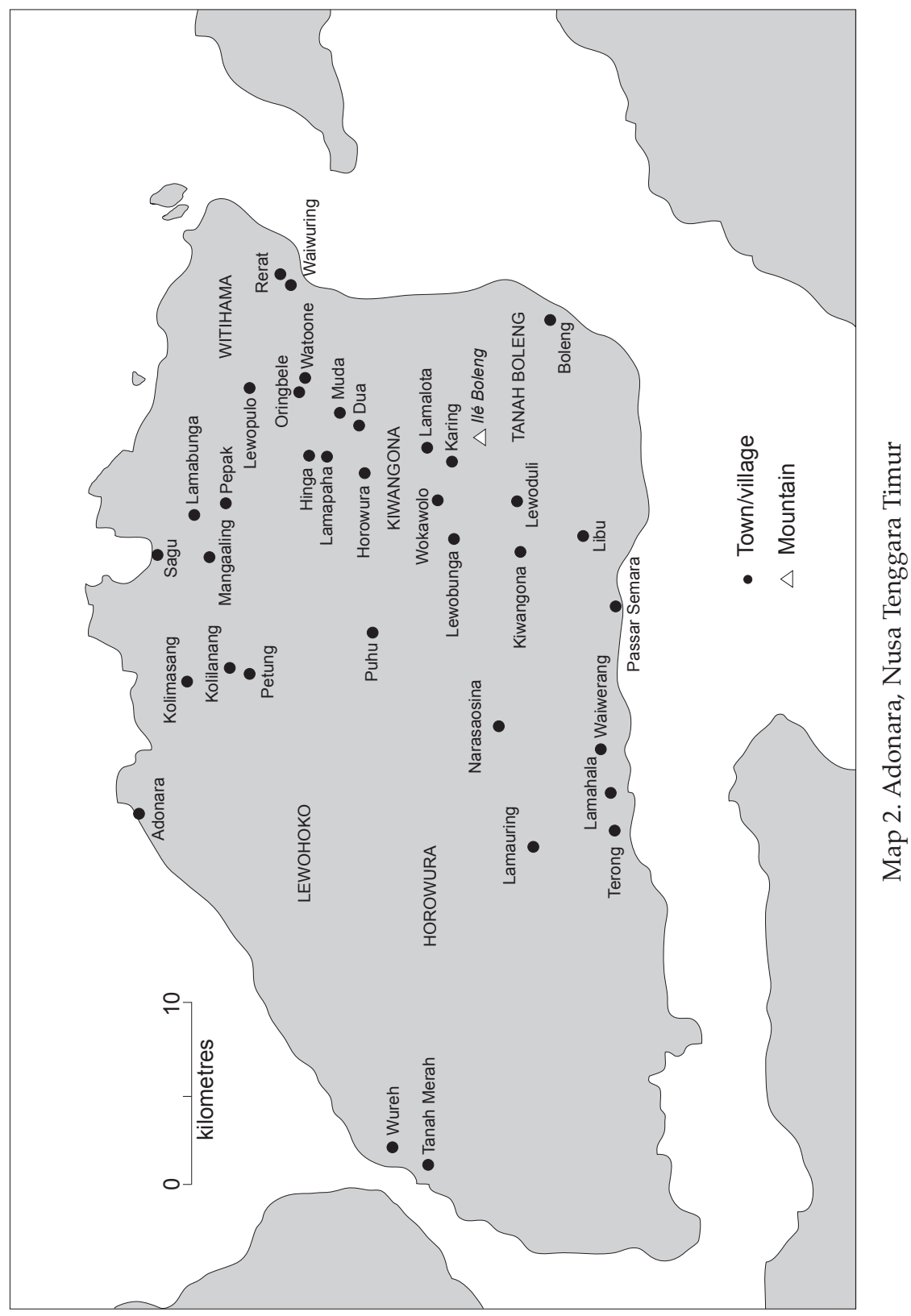


of the Raja of Larantuka the government installed an acting raja who was more amenable to its aims. From then on, government policy in the Timor region became more active. Within six years, Captain J.D.H. Beckering (1911) registered the populations of the East Flores Division and collected firearms. Among local consequences of this sequence of events was that the part of the East Flores Division comprising the rajadom of Larantuka was placed under a powerless figurehead, while the position of the Raja of Adonara was considerably strengthened. Furthermore, the balance of power relations among and within villages was changed. However, the peaceful stability and order that the government wished to instil failed to materialize.

\section{Historical setting}

In the early twentieth century, the Rajas of Larantuka and Adonara were the two most powerful rulers on the islands from eastern Flores through to Lembata. They had been in contact with Europeans since the early sixteenth century, when Portuguese traders and later Dominican priests first appeared in the Solor Strait. The Dutch intervened strongly, if not decisively, against the Portuguese when a Dutch force led by Appolonius Scotte captured the Portuguese fort at Lohayong in 1613. In time, the Portuguese withdrew to Larantuka, while the Dutch signed treaties with the Muslim sengaji (or leaders) of Adonara, Terong and Lamahala on Adonara, and with the sengaji of Lohayong and Lamakera on Solor. These five villages were then and are now known in the local language Lamaholot as the watan léma and in Malay as the lima pantai, that is 'the five shores'. During the seventeenth and eighteenth centuries it was the successive rulers of Lohayong whom the Dutch held to be paramount among their allies. The Portuguese and Catholics became allied in opposition to the Dutch and Muslims. Within the local Lamaholot-speaking population there was a further division between the Demon and the Paji. Broadly (at least from an early twentieth-century perspective, namely that of Don Lorenzo II) the Demon were allied with the Raja of Larantuka and hence

supposed to be kapitan. There is some ambiguous evidence that the leaders of the districts of this realm, such as Witihama, Lamabunga and Hinga, were called kapitan, but were downgraded by Raja Arakian Kamba and given the title kepala béleq ('great leader'). Whether or not this information is correct, in common usage kapitan is normally applied only to the Kapitan of Adonara, an inherited position in the line of the clan Sarabiti Waihale, who claim descent from Enga, a son of a Raja of Larantuka (Sira Napan). In function and prestige, the Kapitan of Adonara was more comparable to the Raja Kedua (second raja) of Larantuka, which was also an inherited position in the family Belantran de Rosari. A thorough description of the structure of the realm of Larantuka can be found in Dietrich (1989:27-37, 53-4, 1997:98-140, 151 note 97, 163 note 196, note 197) and in the sources he cites. 


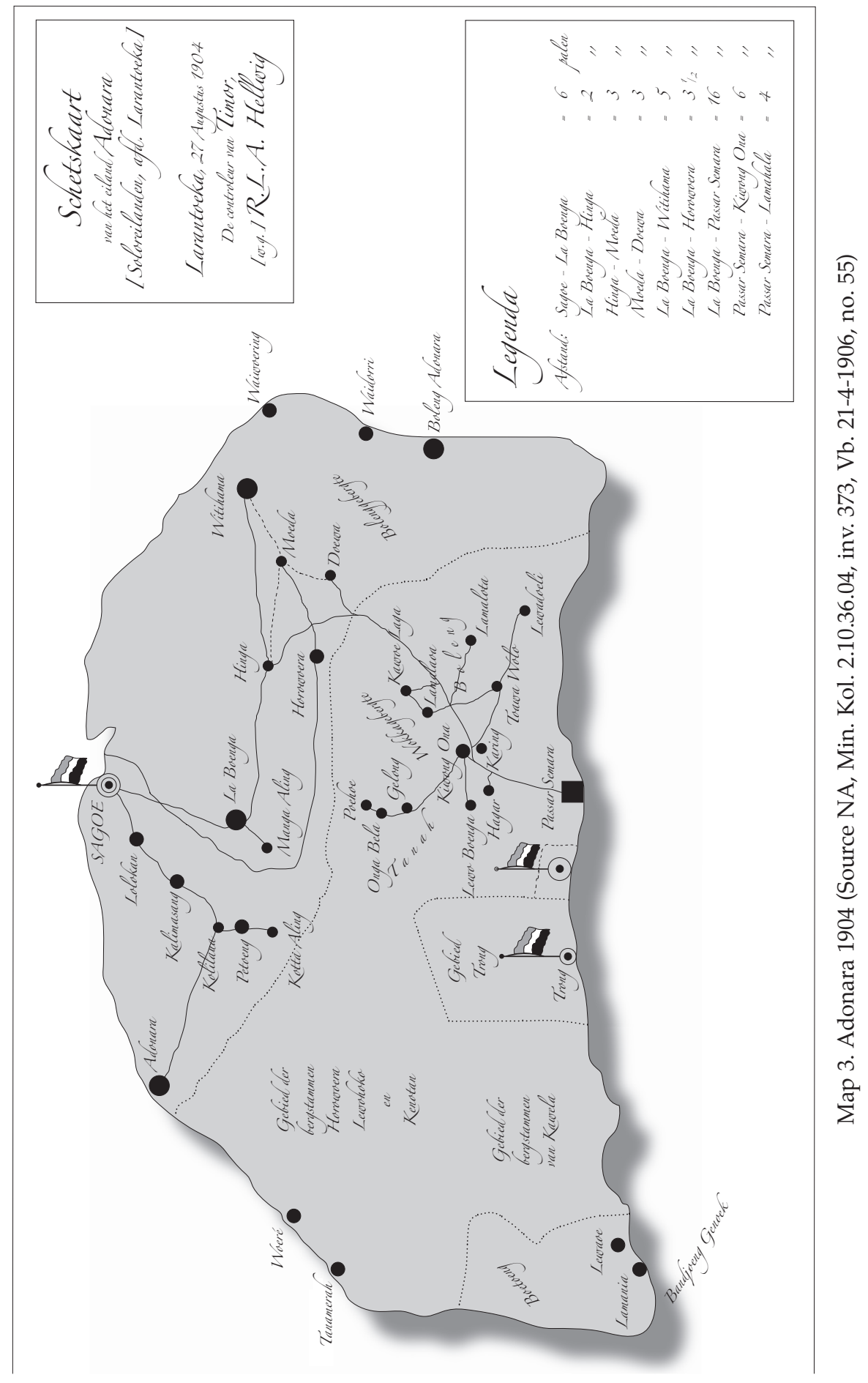


also, for most of the remaining period of their presence in the area (until they ceded their claims to the Dutch in 1851 and 1859), ${ }^{7}$ with the Portuguese. The Dutch in effect were thus inadvertently allied with the Paji, including the domains of all five Muslim rajas. The division between the Demon and Paji was buttressed by myths and provided a framework for many small-scale internal wars. The Catholic priest Paul Arndt devoted a study to the division, which remains an unsurpassed ethnographic source on this subject and which will never be bettered, given the changes which recent history have brought. ${ }^{8}$

\section{Arrest of Don Lorenzo Usi Diaz Vieira Godinho}

At the time of the Hinga war and partly because of the reasons that led to it, the government had reached the breaking point in its relations with the Raja of Larantuka. Before the resident could proceed with the assault on Hinga, he felt that he had to settle matters with the Raja of Larantuka, which he did efficiently on arrival in Larantuka on 1 July 1904 by ordering him on board the Pelikaan and arresting him. The role of Raja Lorenzo was surveyed by Van Eerde (1923:95-103, 105-13) in a summary of the published colonial reports of the time, against which he placed the views expressed by the missionaries. Dietrich (1989:74-9) has provided a critical review of the evidence in the context of a general study of colonialism and the mission on Flores in the first four decades of the twentieth century. These works have recently been supplemented by Steenbrink (2003:90-9) on the basis of access to extensive archives of the Catholic mission, in this case in the context of a general study of Catholicism in Indonesia.

It is well to bear in mind Dietrich's observation (1989:74) that 'the complicated and many leveled development in Larantuka' which led to the dismissal of Raja Lorenzo requires an extensive critique of the sources and that the official descriptions and justifications are insufficient explanations of what was actually going on. Van Eerde (1923:105) characterized the government and mission

7 The Portuguese ceded their holdings on Flores, Adonara, Solor, Lembata, Pantar and Alor in return for a preliminary payment of $f$ 80,000 in 1851 and a supplementary payment of $f$ 120,000 in 1859. The contract was approved by the King of the Netherlands on 20 August 1859 (Staatsblad 1860:1-4). Don Gaspar, Raja of Larantuka, signed an Act of Confirmation in which he recognized the Netherlands Indies Government as his overlord on 28 June 1861 (Bijblad 1865:1867). All six rajas signed the detailed contract on the same date (Bijblad 1865:184-6).

$8 \quad$ Barnes 1987; De Sá 1956:484; Santa Catarina 1733:792-3; Arndt 1938. Over the decades there have been concerted efforts by the government and the Lamaholot communities to suppress the Demon and Paji enmities, with the result that from an ethnographic point of view, the institution is much changed from Arndt's day. 
reports as revealing three perspectives on Don Lorenzo. The first, that of the colonial officers, was that he was an unadulterated native despot. The second, held by the mission, was that he was a fervent Christian. The third, that of the resident, was that he was a native averse to Netherlands government.

Dietrich (1989:4) writes that the decisive date for the beginning of the new colonial period in the Timor Archipelago was the replacement of Resident J. Vijzelaar by Resident F.A. Heckler in April 1902. Even the mission thought that Heckler would be an improvement over the aged Vijzelaar. Heckler's appointment marked the end of the older 'noninterference' policy, which itself was officially introduced in the Timor Residency in $1872 .{ }^{9}$ From now on, more powerful actions were taken, for which the initiative was provided by Heckler (Verbeek 1909:165). Heckler had learned his techniques under J.B. van Heutsz, who together with C. Snouck Hurgronje had transformed the Dutch approach to the war in Aceh through a relentless pursuit of war leaders (Reid 1969:275). Until the Pidië expedition in northern Sumatra in 1898, the leaders of the dependencies on Sumatra 'had been regarded as selfgoverning princes in a contractual relationship with the Netherlands Indies Government' (Reid 1969:278). This relationship was transformed in the Korte Verklaring (Short Declaration), designed by Snouk Hurgronje, in which the former princes submitted to the Dutch East Indies and which was soon introduced in the east.

The 'Atjeh school', as Snouck Hurgronje, Van Heutsz, and their leading associates became known, had apparently proved that attack was the best means of defence; that it was easier to rule a whole than a part. As a result of their energetic policy Atjeh gradually ceased to be the agonizing wound of the Indonesian body politic. The effect of this achievement on Dutch colonial policy as a whole cannot be overrated. Under the Anti-Revolutionary (Calvinist) Government [of the Netherlands] of 1902-5 the 'Atjeh school' was rewarded with the key posts throughout the colonial establishment. Its programme was based on the surmise that Dutch power had first to be unchallengeably established in every part of Indonesia before a start could [be] made in the reformation of Indonesian society which was the aspiration of 'ethici' and liberals alike. Within remarkably few years Van Heutsz's troops asserted Dutch power in almost every state which had previously enjoyed the autonomy of a token submission to Batavia. A diverse and colourful array of traditional rulers were forced to sign the Korte Verklaring and to accept a position where they were incapable of exercising any effective power independent of the Dutch administration. (Reid 1969:280-1.)

9 Hagenaar, 'Beknopte gegevens betreffende het patrouillegebied van het detachement te Larantoeka omvattende Larantoeka, Maoemere, Adonara, Soloren en Lomblen', p. 106, in: NA, $\mathrm{MvO}, 2.10 .39$, Collectie KIT, 1300. 
The previous non-interference policy was motivated by the expense of military intervention and of maintaining a colonial apparatus, while the Timor Residency was a financial liability with no other economic significance (Dietrich 1983:39). In this residency the costs of government sometimes exceeded income, and in an unprofitable residency Flores was among the most unprofitable islands. The outgoing resident in 1868 stated that, 'Here nothing is to be earned for the State Treasury, only something to be lost; [...] to do as little as possible is the most reasonable course' (quoted in Dietrich 1989:1). The draft instructions to the newly appointed Resident L.M.G.A.M. Ecoma Verstege in 1875 stated that, in so far as possible without prejudicing the reputation of Netherlands rule or bringing peace and safety into danger, the resident was to take as the foundation of his leadership a policy of nonexertion, he was to refrain as far as possible from all interference in local disputes, he was not to negotiate new treaties, he was to avoid all inducements to establish new ties with rulers or to renew old ones that had lapsed, and should rulers come to Kupang or approach the officers under the resident elsewhere in order to establish new or renew old relations, he and they were not to give any impression that the government placed any value on such approaches (Colijn 1907:129-30; Lulofs 1911:281-3).

Don Lorenzo prepared himself badly for the sudden policy revolution signalled by the arrival of Resident Heckler. For one thing, he never accepted that his sovereignty derived from the Dutch (Dietrich 1989:292, note 61). As a result of a dispute over paying taxes, in 1900 Don Lorenzo arrested a relative on his mother's side named Ola, who claimed for himself the title of Raja of Pamakayo, Solor, and was preparing to lead the people of Pamakayo in rebellion against the Raja of Larantuka. Ninety of Ola's followers attacked Lorenzo in his house on 13 February. They were beaten off with the loss of 57 dead. All but four of the rest were wounded. On the 14th Ola was executed by being thrown into the sea with stones tied to his neck and feet (M. B. 1900:53-7; Koloniaal verslag 1901:39). Bapa Kaya, son of the former kapitan and subsequently acting Raja of Adonara Bapa Ana and later himself acting Raja of Adonara in the 1940s, expressed the opinion to M.J.H. Wertenbroek - who from 1951 to 1954 worked in Larantuka, Flores as a doctor and who ran the local hospital - that it was the execution of Raja Ola which tipped the scale against Lorenzo with the Dutch authorities. ${ }^{10}$ On Flores the temple (in Malay rumah pemali) in Larantuka had long been a bone of contention for the mission, the Raja of Larantuka, and for not yet converted mountain villages, which had led to a series of wars threatening Larantuka (Koloniaal verslag 1880:25). Don Lorenzo was the first raja not to be crowned in this temple and he refused to rebuild it, which led to complaints reaching Resident W.C. 
Hoogkamer. Hoogkamer came to Larantuka on 13 August 1890, unfortunately just as Pastor Ten Brink was dying, to investigate why the raja was not permitting his subjects to practise their local adat (customary rituals and practices), a right which had been guaranteed them by the government. Lorenzo (and the mission) seems to have come out of this confrontation well. ${ }^{11}$ In 1901, the Raja of Larantuka interfered in a conflict in Sikka (Koloniaal verslag 1902:92). In September 1902, Lorenzo travelled with several prahu and 1,000 followers to collect taxes on the north coast of Flores in a region disputed with the Raja of Sikka (Koloniaal verslag 1903:103-4). The raja continued to be in dispute with the villages of Leloba and Wailolong behind the Mandiri volcano (Koloniaal verslag 1900:46).

On Adonara, in 1895 people from the western Adonara region Horowura, subject to the Raja of Larantuka, murdered a man from the village of Lamauring, subject to the Raja of Terong, provoking a war. In May 1897, all of the villages in the region of Terong were burned down, except for Terong itself. Stripped of their possessions, the population had to flee to Solor. Terong was brought as well as possible into a state of defence. It was repeatedly disturbed, and again and again people who dared to leave the village in search of food were killed. In June the resident visited Terong and left a detachment of armed police behind. Attempts to reconcile the opposing parties failed because the Raja of Terong did not want to content himself with the defeat and the Raja of Larantuka did not want to hear of peace until receiving compensation for the costs of war and the death of his subjects. At the beginning of August the situation in Terong became so dangerous that the posthouder (post holder), then stationed in Terong, and the police attempted to drive the attackers away. There were no further attacks, but people from Terong continued to be killed. Efforts by Terong to wreak revenge failed because auxiliary troops brought in from elsewhere ran out of food and had to return home. When the resident visited again in October, he deemed the situation hopeless, so he withdrew the police and ordered the post holder to move to Larantuka. The population of Terong, no longer able to hold out, transferred with its movable possessions to Solor. Thereafter the empty village was burned to the ground (Koloniaal verslag 1898:25). The situation remained at a stand-off until late 1902, when the government intervened. Terong was allowed to return to Adonara and rebuild its village in January 1903, and a feast of reconciliation was held (Koloniaal verslag 1903:104). However, Kakang Juga of Kiwangona continued to threaten the main villages in the district of the Raja of Terong,

11 Don Lorenzo pointed out to the resident that the rebuilding of the temple necessitated the taking of heads for the ritual associated with it (Heslinga 1891:81-3). See also Guru Olla Diaz Vieira, 'Hikajat asalusul Radja Larantuka dan beberapa keterangan tentang orang jg tsb. dalam stamboom', in: KITLV, Collectie Wertenbroek. 
some of which he burned again after they had been half rebuilt. Although he did not directly attack Terong itself, he continued to provoke it and through his threats brought an end to the restored friendship between Terong and the region of Horowura under the Raja of Larantuka. ${ }^{12}$

The government finally concluded its negotiations with the Raja of Larantuka begun in 1898 concerning the declaration he was to make recognizing the right of the government to collect taxes in his region and to take over the already existing taxes in return for compensation. Initially the raja had declared himself entirely unwilling to agree to such an arrangement and demanded 'extravagantly high and unmotivated' compensation. ${ }^{13}$ When he finally made the required declaration in November 1902 in the presence of his subordinate leaders, his 'prestige in the outside' was broken. Limits were set to the lack of pliability of the mightiest and slyest and most arrogant ruler in the region (Koloniaal verslag 1903:104). Both the raja and the mission were surprised by this new approach. 'A more powerful and more independent prince had no place next to the government; the new policy of unrestricted subjection of the princes to the "well meaning leadership of the government" was felt earliest therefore in Larantuka' (Dietrich 1989:74, 292 note 61 , note 63 ).

When the Raja of Larantuka became involved, through the activities of the Kakang Juga of Kiwangona, in the conflict in Hinga his fate was sealed. The resident together with armed police on the Pelikaan and accompanied by the Mataram returned from Maumere and stopped at Larantuka on 1 July. Lorenzo, who had made a practice of never appearing in Larantuka when the resident was there, had been ordered to report to the resident when he next appeared and was immediately ordered on board the Pelikaan, where he was declared divested of his position and sent as prisoner to Kupang, Timor. ${ }^{14}$ According to the account carried in the Mataram (28 February 1907), ${ }^{15}$ Raja

12 Koloniaal verslag 1905:78. Heckler to governor-general, 27-6-1904, in: NA, Min. Kol., 2.10.36.04, inv. 373, Vb. 21-4-1906, no. 55.

13 Raja Lorenzo had requested $f$ 2,000 per month. He also says that Resident Vijzelaar had determined that Terong should pay Kiwangona $f$ 4,000 in compensation for the fact that Juga's brother's son had been killed in the war, but that Heckler had forbidden Terong from paying. See Diaz Vieira Godinho to n.n., c. 1904, pp. 1, 3, in: Arsip Regio, Ende, Laan 1962-68:1237-44; Diaz Vieira Godinho to governor-general, c. 1904, p. 2, in: Arsip Regio, Ende, Laan 1962-68:1241.

$14 \quad$ Koloniaal verslag 1905:78; B. 1905:977; Onlusten 1907:369-70; Hagenaar, 'Beknopte gegevens betreffende het patrouillegebied van het detachement te Larantoeka omvattende Larantoeka, Maoemere, Adonara, Soloren en Lomblen', pp. 6-7, in: NA, MvO, 2.10.39, Collectie KIT, 1300. Heckler to governor-general, 11-7-1904, p. 1, in: NA, Min. Kol., 2.10.36.04, inv. 373, Vb. 21-4-1906, no. 55; Heckler to governor-general, 12-8-1904, 'Kort verslag omtrent den toestand en de voornaamste gebeurtenissen in de Residentie Timor en Onderhoorigheden over de maand Juli 1904', pp. 1-2, in: NA, Min. Kol., 2.10.36.04, inv. 430, Vb. 25-1-1907, no. 52.

15 Quoted in KITLV, Collectie Wertenbroek. 
Larenzo came out of his house and saw the Pelikaan. He then went to the post holder to ask if anything unusual was going on, but found there the controleur (deputy commissioner) of Kupang, who told him to go on board. The raja wanted to dress himself properly, but was told to just board the boat, where the resident told him, 'Raja, you supported the mountain people of Kiwangona in their fight against the Raja of Adonara and therefore I take you as prisoner to Kupang. Pending later approval of the government, I declare you suspended from the Rajadom.' A contemporary report in the Javabode (28 July 1904, taken over from the Soerabajaasch Handelsblad $)^{16}$ claims that the raja had called mountain people to town and ordered Juga to overrun Larantuka in case he was deposed. However, the mountain people had run away during the night. Four hundred armed men from Kiwangona did show up at Wureh on the northwest coast of Adonara with the aim of crossing the strait, but when they saw that Larantuka was occupied by a strong force, they disappeared. Heckler deemed the people of Larantuka were not to be feared because they hated the raja, although the missionaries thought they were simply cowed by the military force of the government. ${ }^{17}$ Immediately after the arrest of Don Lorenzo, the resident priest Joseph Hoeberechts bitterly reproached Deputy Commissioner R.L.A. Hellwig for the government's actions against the raja, saying that through the arrest of Raja Lorenzo the work of the mission had been destroyed. Heckler demanded that Hoeberechts and his fellow priest H.J.H. van der Velden be withdrawn from the region. ${ }^{18}$

From Kupang Raja Lorenzo was sent as a fourth-class passenger by ship to Surabaya. ${ }^{19}$ He spent the rest of his life, until November 1910, in exile in Yogyakarta, Java. All of his possessions and wealth having been confiscated by the Netherlands Indies government, he survived on a pension of $f 50$ per month, $f 25$ of which went for lodgings (Steenbrink 2003:96).

16 Quoted in KITLV, Collectie Wertenbroek.

17 Onlusten 1907:370; Dietrich 1989:75-6; Hagenaar, 'Bijlage: Onlusten op Flores in 1904 en 1905, behoort bij Beknopte gegevens betreffende het patrouillegebied van het detachement te Larantoeka omvattende Larantoeka, Maoemere, Adonara, Soloren en Lomblen', p. 7, in: NA, $\mathrm{MvO}$, 2.10.39, Collectie KIT, 1300; Heckler to governor-general, 11-7-1904, p. 10, in: NA, Min. Kol., 2.10.36.04, inv. 373, Vb. 21-4-1906, no. 55; Heckler to governor-general, 12-8-1904, 'Kort verslag omtrent den toestand en de voornaamste gebeurtenissen in de Residentie Timor en Onderhoorigheden over de maand Juli 1904', pp. 3-4, in: NA, Min. Kol., 2.10.36.04, inv. 430, Vb. 25-1-1907, no. 52.

18 Heckler to governor-general, 11-7-1904, pp. 3-5, 17, in: NA, Min. Kol., 2.10.36.04, inv. 373, Vb. 21-4-1906, no. 55.

19 Diaz Vieira Godinho to governor-general, c. 1904, p. 3, in: Arsip Regio, Ende, Laan $1962-$ 68:1237-44. 


\section{Causes}

The causes of the Hinga war appear to have been various. Conflicts between the Raja of Adonara and Hinga seem to have been of long standing. Raja Arakian Kamba's father and predecessor Kamba Begu had twice been repulsed by Muda after having defeated all of the surrounding villages (Dietrich 1989:288, note 28; Onlusten 1907:371). The Dutch attributed the war to the machinations of the Raja of Larantuka, who spurred Juga, Kakang of Kiwangona, to armed assaults in the region belonging to the Raja of Adonara with the aim of stripping the mountain villages from Adonara and bringing them under the influence of the Raja of Larantuka. In April, May and June 1904 the irregularities and disputes on Adonara steadily increased, principally 'through the brutal activities of Juga' (H. B. 1905:976) and the steadily spreading rebellion of Hinga. On 28 April, Hinga fired on Lamabunga. In April and June, Juga attacked Horowura belonging to Adonara and also in June the village of Honehama. He also interfered in a dispute between the villages Petung and Kotaaling, with the result that the last left the side of Adonara. Hinga fought with the village of Witihama, which remained loyal to Adonara, leading to deaths on both sides. The government thought that Juga and the mountain people of Kiwangona were supporting Hinga's rebellion from the Raja of Adonara.

Resident Heckler accused the Raja of Larantuka of double dealing. Although he claimed that he ordered Juga to desist in his interference in the affairs of the rajadom of Adonara, Juga continued his activities. Nevertheless, he frequently travelled to Larantuka, where he always stayed in the raja's house. Furthermore, when the resident on the government's steamship Pelikaan passed Larantuka during disruptions on the north coast of Flores in May and June 1904, the raja always left town only to reappear after the ship had returned. Meanwhile, in his absence a threatening group of mountain people made their appearance in Larantuka. ${ }^{20}$ His avoiding Larantuka when the ship appeared was in fact related to many other causes of tension between the raja and the government and not just to the activities of Juga.

20 Heckler to governor-general, 27-6-1904, pp. 2-6, in: NA, Min. Kol., 2.10.36.04, inv. 373, Vb. 21-4-1906, no. 55; Heckler to governor-general, 16-6-1904, 'Kort verslag omtrent den toestand en de voornaamste gebeurtenissen in de Residentie Timor en Onderhoorigheden over de maand Mei 1904', pp. 2-4, in: NA, Min. Kol., 2.10.36.04, inv. 430, Vb. 25-1-1907, no. 52; Heckler to governor-general, 'Kort verslag omtrent den toestand en de voornaamste gebeurtenissen in de Residentie Timor en Onderhoorigheden over de maand Juni 1904', p. 3, in: NA, Min. Kol., 2.10.36.04, inv. 373, Vb. 21-4-1906, no. 55; Heckler to governor-general, 11-7-1904, in: NA, Min. Kol., 2.10.36.04, inv. 373, Vb. 21-4-1906, no. 55; Hagenaar, ‘Bijlage: Onlusten op Flores in 1904 en 1905, behoort bij Beknopte gegevens betreffende het patrouillegebied van het detachement te Larantoeka omvattende Larantoeka, Maoemere, Adonara, Soloren en Lomblen', pp. 5-6, in: NA, MvO, 2.10.39, Collectie KIT, 1300; Koloniaal verslag 1905:78; B. 1905:976-7. 
In Heckler's view, Kiwangona secretly backed up by the Raja of Larantuka had supported Hinga. The government repeatedly pressed the raja to forbid Juga to mix in external situations, but felt that experience had shown that they could not rely on the help the raja promised. Although he agreed to accompany the civiel gezaghebber (district commissioner) on a trip to Kiwangona which was delayed for nine days to accommodate him, on the night before departure he begged off on not very convincing grounds and limited himself to sending some guides, who however advised the district commissioner against visiting Kiwangona on the pretext that ceremonial restrictions made the arrival of strangers unwelcome. Nevertheless, he travelled to Kiwangona and found on his arrival that the village had been deserted by almost all male inhabitants. At some distance around a hundred of them were at the time on Adonara territory engaged in a battle with people from that rajadom, so that he could only reach Sagu by a detour. ${ }^{21}$ The Raja of Adonara called to his aid auxiliaries from Lewotolok on Lembata and from Kédang, Lembata, which itself had recently been forced by the Dutch to submit itself to the Raja of Adonara. The government placed fifteen armed police in Lamabunga in October 1903 to protect the Raja of Adonara, whereupon Juga called all of the mountain villages in his sphere of influence to war. Karing refused to obey and was attacked and burned with the loss of forty of its inhabitants, the rest fleeing to Boleng on the south coast which came under the Raja of Adonara. On 5 October, the Raja of Adonara supported by the police and the auxiliaries from Lembata attacked Hinga, but they were beaten back. ${ }^{22}$

According to Arndt (1938:50) the Hinga war was caused by bride theft, leading to a war between two villages of the Paji region under the Raja of Adonara. The Raja of Adonara sided with the village of Lamabunga, situated closer to his own village of Sagu than Hinga. Luli Hada, who was leading the Hinga revolt, travelled to Kiwangona in the Demon region, where the Raja of Larantuka was attending a feast. Luli Hada brought an offer from Hinga to submit to the Raja of Larantuka and become Demon. The Raja of Larantuka was said to have agreed to this arrangement and had a buffalo slaughtered to seal the agreement. The raja and Luli Hada together ate the liver of the buffalo. Hinga thus became briefly Demon. ${ }^{23}$ The Raja of

21 Raja Lorenzo later denied that people of Kiwangona were involved in this incident. According to him, people from Witihama and Hinga were fighting each other on Kiwangona territory. See Diaz Vieira Godinho to n.n., c. 1904, p. 3, in: Arsip Regio, Ende, Laan 1962-68:1237-44. 22 Heckler to governor-general, 27-6-1904, pp. 4-5, in: NA, Min. Kol., 2.10.36.04, inv. 373, Vb. 21-4-1906, no. 55.; Koloniaal verslag 1903:105-6; Verbeek 1909:173-4; Dietrich 1989:68.

23 According to Raja Lorenzo, 19 years before, that is circa 1885, people from Hinga and Witihama had killed Juga's son and 19 others. The Raja of Adonara did not want to settle that affair, and therefore Juga went to war. Consequently Hinga became frightened and came to submit to rule by Kiwangona. Subsequently Raja Lorenzo called upon both Kiwangona and Hinga 
Adonara, however, called for Dutch troops and the Raja of Larantuka was placed under arrest.

Kalesar (n.d.a:40-1) lists several causes of the Hinga war. The first was a dispute between two brothers, Paron Kian and Paron Bubu. In this dispute, about which he tells us nothing further, Paron Kian fled to Hinga and sought protection from Lega Nama and Luli Hada, while Paron Bubu fled to Lamabunga where he asked help from Sabon Nama, who in turn asked help from the Raja of Adonara, who turned to the Dutch. On 1 October 1903, the fifteen policemen placed in Lamabunga by the Raja of Adonara delivered shots of warning to Hinga. Thereupon Luli and his followers fled to Muda.

A second cause was a dispute over land and coconut trees, about which Kalesar also provides no further information.

The third cause was an oha bĕlone, in Dutch records in Malay tikar bantal, a war of the 'mat and pillow', that is a war caused by a dispute over women. In one incident Ola Masan, Kopong Boli, and Mado Pati of Riang Tobi clan fled to Hinga. This dispute was occasioned by rivalry between the brothers Ola Masan and Sabon Belen over their own sister Ina Hala. Hinga supported Ola Masan and his followers. According to the grandson of the Raja of Adonara Arakian Kamba, the Raja of Adonara tried to stop the war between Sabun Bele and Ola Masan by ordering that a white flag be erected as a sign to stop the fighting. Kopong Boli, an elder brother of Ola Masan, cut down the white flag and cursed Raja Arakian Kamba. The raja called the heads of Lewotolok and Kédang on Lembata, who made war on Hinga, but could not defeat it. Then Arakian Kamba, his Kapitan Bapa Ana, and the Kapitan of Kédang, Bapa Rian, conferred and decided to turn to the Dutch for help. Another such incident involved the Raja of Adonara himself. Baro Nama was engaged to Benga Tupen of Lamabunga, sister of Sabon Nama, for whom he had already given three elephant tusks as bridewealth. One day the Raja of Adonara vis-

for support in a war against Lewoloba in eastern Flores. See Diaz Vieira Godinho to n.n., c. 1904, p. 1, in: Arsip Regio, Ende, Laan 1962-68:1237-44. After that a subject of the Raja of Adonara named Ola Hide killed several people under Larantuka and chased others from their fields. The Raja of Larantuka 'divided medicine' for a war against the Raja of Adonara, but was stopped when Resident Vijzelaar ordered the Raja of Adonara to pay $f 500$ in compensation, which the Raja of Larantuka thought was inadequate. Nevertheless, the Raja of Larantuka says, he ordered that there be no more war. However, Resident Heckler thought that he had distributed more 'medicine' for renewed war. He stated too that the difficulties between Koli and Kiwangona began when Gelu from Koli killed someone from Kiwangona. Raja Lorenzo requested that Gelu be surrendered to him to be exiled, but District Commissioner Misero and the Raja of Adonara refused. Subsequently more fighting broke out. Raja Lorenzo complained that instead of admitting their mistakes in not arresting Gelu, Misero and the Raja of Adonara wrote to the resident blaming Raja Lorenzo. He delayed in following orders to capture Juga because many Christians were working fields on Adonara and would be exposed to retaliation. See Diaz Vieira Godinho to n.n., c. 1904, pp. 1-3, in: Arsip Regio, Ende, Laan 1962-68:1237-44. 
ited Lamabunga and went to the house of Sabon Nama, where he saw Benga Tupen, whom he married.

The fourth cause had to do with tax. In this incident the leaders of Hinga Luli and Nama Sabon ordered the people of Hinga not to pay tax to the Raja of Adonara.

The fifth cause was an agreement between Hinga and Kiwangona not to attack each other. This agreement was strengthened by an oath in Kiwangona witnessed by the Raja of Larantuka. Hinga wanted to assure itself that when it fought Lamabunga, it would not be attacked from the rear by Juga and Kiwangona.

A rather different account given me as to how Arakian Kamba became involved in this war is that his wife Peni Eroq from Lamabunga persuaded him to join in and support Lamabunga (see also Dietrich 1989:68).

The Dutch seemed at first somewhat confused as to which villages were in rebellion. T.C.K. Hagenaar lists Hinga, Witihama, Lamabunga, and Muda. ${ }^{24}$ In fact it appears that most of the villages involved were split. For example, it was the head of Dua, which later was to provide refuge to the rebels and eventually submitted to the Dutch, who acted as the guide for Van den Borg. Only a faction from Lamabunga fled to Hinga, whereas the village itself remained loyal to the Raja of Adonara, from whom they received support. As for Witihama, its leadership too remained loyal to Adonara. Only a segment who were opposed to the head of Witihama joined the Hinga rebels.

I do not have further details about the internal situation in Lamabunga and Hinga, but the relationships in Witihama have been explained to me by descendants of the contesting parties. The split in Witihama derived from bloodshed within the ruling family. Figure 1 shows a simplified version of the descent line of the ruling clan, which has recently begun calling itself Goran Tokan (an allied branch of Lama Tokan clan) and which has a tradition of deriving from the Moluccas (Seran Goran). At some time before the Hinga war, Witihama had been engaged in a battle at Muda (called Nuha Muda) in which the head of Witihama, at that time Buang Durang, and his brother Lésu Tokan died. The youngest brother Kéi Tokan (Kéi Lésu) then became head of Witihama. Subsequently the son, Tenuen Tokan, of Kéi Tokan's uncle Puru Duli committed adultery with Téna, the wife of Kéi Tokan. His father told Kéi Tokan to beat gongs and drums and announce that Téna was no longer his wife. Kéi did not want to do that and instead he and his followers fought with Puru Duli and Tenuen and their followers whom they drove to

24 Hagenaar, 'Beknopte gegevens betreffende het patrouillegebied van het detachement te Larantoeka omvattende Larantoeka, Maoemere, Adonara, Soloren en Lomblen’, p. 113, in: NA, $\mathrm{MvO}, 2.10 .39$, Collectie KIT, 1300. 
Hinga. Tenuen was subsequently killed in Lamahala by people from Tanah Boleng. Lamablawa clan in Witihama was split by this war, with a faction siding with Puru Duli, while the rest supported Kéi Tokan. After the outcome was clear, those who supported Puru Duli settled in Hinga. Among this Lamablawa group were Géo Téna and Bebe Kéwa.

Géo Téna was a somewhat distant relative of Bebe Kéwa, who was the older of the two, but they were especially close because Géo Téna's grandmother and Bebe Kéwa's mother were sisters. Géo Téna's father Arakian and Bebe Kéwa therefore were close, and the relationship passed on to Géo Téna (see Figure 2). Arakian's mother was from the Goran Tokan line settled in Watoone, but he seems to have had relations with the wives of the men of this line. Indeed, it is said that Arakian killed many people in Goran Tokan, despite his ties to them. His branch of Lamablawa clan engaged them in a war called Nuha Goqok, after the hamlet in which his branch lived, Goqok, to the north of Witihama proper. Arakian was an unerring shot and killed a man from Goran Tokan in this war. His group intended to drive Goran Tokan from Witihama, but when they neared the village, one among them told them that if they went ahead with the plan they would have no bailake (mother's brother) to come to their grave. The mother's brother or his equivalent plays a vital role in funerals. Nevertheless, Goran Tokan requested permission of Raja Arakian Kamba to kill Arakian. Arakian travelled with four dogs and a horse. The dogs immediately let him know if an enemy was approaching with a weapon, so it is said, and he would kill the attacker, so that he was virtually invulnerable. However, somehow once when he was passing through Hinga, Buang Duran waylaid him and killed him.

Géo Téna was also an expert marksman. During the assault on Muda, at the same time that Van den Borg was shot, Raja Arakian Kamba was struck in the chest by a bullet, which however hit a gold medallion and was deflected. Arakian Kamba always insisted that he had been shot by Géo Téna, but in fact he was actually shot by Mado Masan of Lamapaha, the village adjacent to Hinga. Van den Borg was shot by Ola Ama (Kalesar n.d.a:42). Ola Ama was never caught or punished. According to the Kapitan of Adonara at that time, as his son told me, the Dutch troops forgot to say goodbye (pamit) to the kapitan when they left Sagu to march on Hinga. This omission caused the kapitan, Bapa Ana, to say that the commander would die, which is what happened.

After the war, of the ringleaders, Luli Hada of Lama Tokan clan in Hinga went unpunished and eventually died in the village, but Nama Sabon of the same clan was imprisoned in Yogyakarta. Several others were sent away to prison and died elsewhere. Bebe Kéwa hid in the mountains. He was called, however, and walked down the road through the hamlet of Lamablawa (immediately west of Oringbele) carrying an elephant tusk. When asked, 


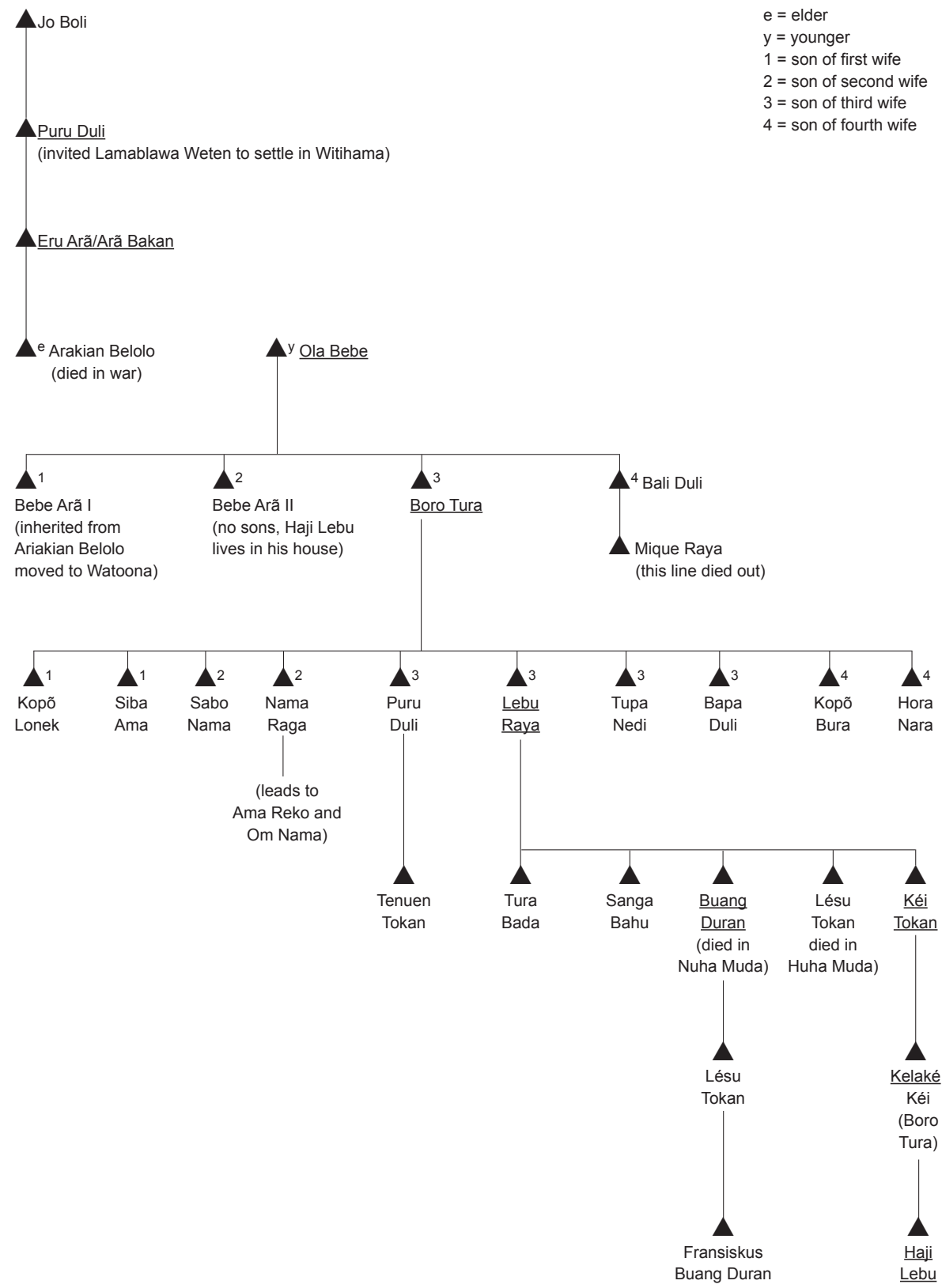

Figure 1. Genealogy of the leaders of Witihama (the underling indicates that these are the men who occupied the office of head of Witihama) 
he said that he was carrying the elephant tusk as travel provision. At Lamabunga, he was tied up. Women from Hinga chewed sirih pinang with candlenut which they spit all over his body in order to capture his spirit. People placed a sack on the ground and put him on it. Two people picked it up and carried him to Sagu, so that he would not escape. At Sagu he was put on the Dutch ship. The government sentenced Bebe Kéwa to 20 years in prison where eventually he died.

Géo Téna wanted to go in Bebe Kéwa's place, but Kéi Tokan of Witihama did not agree. Kéi Tokan wanted Géo Téna to marry into his family so that there would be a descent line from Géo Téna related to his own. Having him in Witihama was a way of keeping an eye on him. Once they brought him to Witihama and he escaped during the night to Lewotolok, Lembata. On another occasion the head of Witihama had the framework of a house made in Lewopulo and brought it to Witihama to be erected for Géo Téna. Eventually Géo Téna married Dae Wotan of Goran Tokan clan and settled in the hamlet of Lamablawa. However, other members of this splinter group remained in Hinga, where their descendants, some of whom I know quite well, still reside.

After the Hinga war, at Pepak the government handed out sprouting coconuts for people to plant, ten nuts per family head. Raran Belai of the Kole section of Lamablawa clan went to Sagu, where Raja Arakian Kamba asked him whether he had already received his coconuts at Pepak. He answered that he had not yet, but that he had seen that Géo Téna had taken his and planted them at Rerat (on the east coast). Arakian Kamba was startled and replied 'Géo Téna? What does he have to do with you?' 'We are clan brothers', was the answer. Arakian Kamba said, 'Adu, if so, I cannot easily go to Waiwuring [the fishing village and market near Rerat]'. That was because he was afraid of Géo Téna. Arakian Kamba then said, 'In that case, géré be ékoro (root them up)'. This Raran Belai seems to have done, although he missed four. There were bad relations between Géo Téna and Raran Belai, whereas Arakian Kamba and Raran Belai both had mothers who came from Lamahala, whence Raran Belai's second name derived after the notorious Belai Seraka who involved Lamahala in a series of bloody disruptions in the nineteenth century and was eventually imprisoned at Pekalongan, Java, by the government (see below). Raran Belai wanted to capture Jogo Nama and give him to Arakian Kamba as a slave because of a disagreement over land. According to one account, Jogo Nama went to the fields, where he met Raran Belai who told him vulgarly, 'if you come to the fields, bring a spear and spear my buttocks'. Jogo Nama returned and told Géo Téna. They both returned to Raran Belai. Jogo Nama asked Raran Belai to repeat what he had said before. While that was going on, Géo Téna stabbed him from behind. Other people say that Jogo Nama stabbed Raran Belai on the orders of Géo 


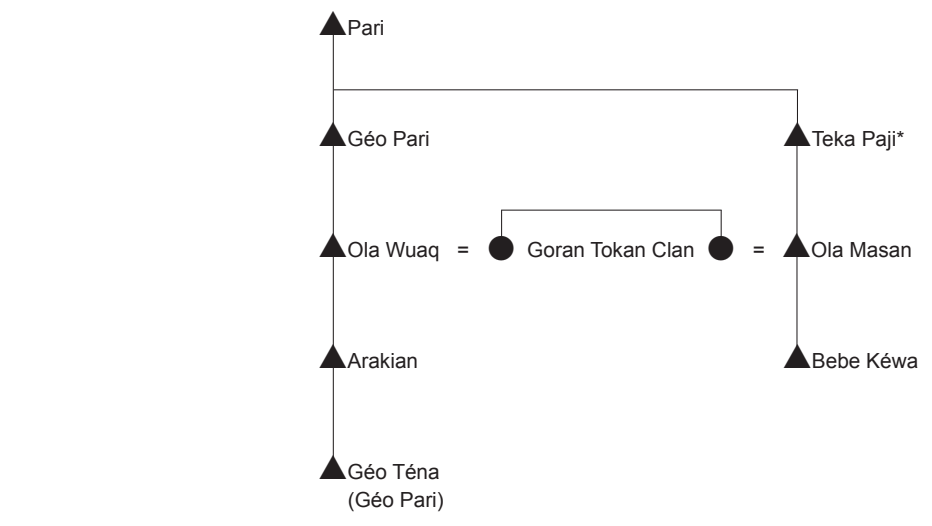

* In eastern Adonara Pari/Payi/Paji/Pagi are all common pronunciations of the same word.

Figure 2. Genealogy of Géo Téna and Bebe Kéwa of Lamablawa Clan

Téna, but still others say that this claim is not true. It was sufficient reason for Jogo Nama that Raran Belai wanted to capture him and give him to Arakian Kamba as a slave. Jogo Nama was sentenced to four years in prison. Géo Téna eventually died by falling from a tree, a form of death that is generally regarded as highly inauspicious and classified as a bad death, which calls for a ceremonial search for the cause of the misfortune. His son, whom I know quite well, had a very different life from his father and now lives as a retired government official in Witihama.

\section{Sinyo Luis Belantran de Rosari}

The government appointed in place of Don Lorenzo his relative (father's sister's son) Sinyo Luis Belantran de Rosari of the family which traditionally supplied the second Raja of Larantuka (raja kedua) as acting raja, although according to A.M. Hens his authority remained only nominal. ${ }^{25}$ This curious figure had the good fortune to be a friend of the district commissioner, the Protestant J. Misero, who obviously spoke for him despite a dubious past. Once during a fight with his wife Nona Muda from Balela (Batu Besar, part of present-day Larantuka ${ }^{26}$ ) he shot her from under the chin through

25 Hens, 'Memorie van Overgave der Afdeeling Flores', 30-6-1916, deel 2, p. 167, in: NA, Collectie Le Roux, inv. 4.

26 For a detailed description of the rather complex division of the historical and modern Larantuka, see Dietrich 1997:22-3, 28-62, 115-7, 124-6. 
the head. Resident S. Roos (1881-1883) then banned him to Kupang. Later he returned to Larantuka, where Raja Lonrenzo eventually put him in jail because of his activities in Konga, Flores, and then banned him in 1900 to Tanah Merah, Adonara. On one of Raja Lorenzo's expeditions to Sikka, they captured Rabi the leader of Habi Gahar. He was wearing heavy golden earrings, which Sinyo Luis wanted. When Rabi could not free them from his ears, Sinyo Luis cut them loose. When Raja Lorenzo heard this he was so angry that he rent his garments. ${ }^{27}$ Sinyo Luis returned to Larantuka after Lorenzo was deposed. ${ }^{28}$ In the short time remaining to him, according to Resident Heckler, 'he rebuilt a rumah pemali [temple], a lodging and meeting place for the chiefs of the mountain villages, which had been left in decay by his predecessor. Through this act he won closer contact with the mountain chiefs.' (Steenbrink 2003:97.) He was not officially recognized as acting raja until 12 December 1906. Five months later, on 1 May 1906, he died from a serious stomach disease. ${ }^{29}$

\section{The move against Kiwangona}

The next measure to be taken, after the arrest of Raja Lorenzo and before the action against Hinga, Muda and Dua, was to apprehend Juga. On 25 July 1904 the resident together with Dutch troops, armed police, and the acting Raja of Larantuka and sixty of his followers left Larantuka with the Pelikaan and the Mataram for Pasar Semara (Semara Market) ${ }^{30}$ on the south coast of eastern Adonara. On 26 July 1904, around one thousand auxiliary troops sent by the Rajas of Terong, Lamahala, Lamakera and Lohayong arrived, joining 160 armed men from Raja Adonara who two days before had been brought to Terong. On the same day this collection marched up the gradual slope 6 paal (5.6 miles or 9 kilometres) to Kiwangona. Before reaching the village, the column found Jari Amang, a nephew of Juga, waiting for them with a white flag. He told them that Kiwangona wanted to surrender and that Juga was in the village. Leaving the auxiliary troops outside, the rest of the column

27 Heckler to governor-general, 11-7-1904, p. 13, in: NA, Min. Kol., 2.10.36.04, inv. 373, Vb. 21-4-1906, no. 55; Guru Olla Diaz Vieira, 'Hikajat asalusul Radja Larantuka dan beberapa keterangan tentang orang jg tsb. dalam stamboom', in: KITLV, Collectie Wertenbroek.

28 KITLV, Collectie Wertenbroek.

29 Koloniaal verslag 1906:75, note 1; KITLV, Collectie Wertenbroek.

30 The Semara market is now completely abandoned, but was an important trading site before the Dutch established what eventually became the principal town on Adonara at Waiwerang. Nothing now remains of Pasar Semara but two disused wells and a water trough. Pasar Semara is located at Pantai Semara (Semara Shore) just a few miles east of Waiwerang on an accessible and reasonably sheltered coast. 
entered Kiwangona, which was still partially occupied. Juga was not found until Raja Adi of Lamahala looked for him and brought him in. Juga claimed always to have acted on the orders of Don Lorenzo. Overcoming his resistance, they bound him and carried him by litter to the Mataram under arrest. Later the assembled rajas at Larantuka sentenced him to 20 years of forced labour in chains outside of the region. Jari Amang, who had fled in fear when ordered to accompany the troops and in the process had been wounded, reported on 28 July. Because it appeared to be principally his doing that Juga gave up the rebellion and because he was the next rightful holder of the post, it was decided to appoint him head of Kiwangona, which was fined $f 3,000$, of which $f 1,000$ was to be paid the next day. ${ }^{31}$

\section{Aftermath of the Hinga war}

Having settled matters with Kiwangona, the Dutch force then turned its attention to Hinga, Muda and Dua, with the results described above. However, the problem of the dispersed population of these villages remained. The Deputy Commissioner of Kupang and the police force returned on 7 August to Horowura, a village lying in the territory of the Raja of Adonara between Hinga and Kiwangona, where they formed a bivouac. One third of the force was left there, while the rest camped in Lamabunga, where the District Commissioner and the Raja of Adonara remained. The forces patrolled from these strong points, killing and capturing many. Most of the destitute refugees from Hinga found protection in some of the villages which made up Kiwangona, especially Lewoduli. The head of Kiwangona was unable to drive them from his land, until the deputy commissioner informed him that Kiwangona would again be regarded as an enemy, if he allowed people from Hinga in his land. The population of Hinga was then forced to camp under open skies on a dry highland between Lewoduli and Lamalota. They were in great want and their stealing from the fields of Kiwangona villages brought them into conflict with these villages. Eventually various groups from Hinga gave themselves up to the loyal heads of Witihama and Horowura and were for the most part interned on Lembata.

31 Koloniaal verslag 1905:79; Onlusten 1907:371; Heckler to governor-general, 12-8-1904, 'Kort verslag omtrent den toestand en de voornaamste gebeurtenissen in de Residentie Timor en Onderhoorigheden over de maand Juli 1904', pp. 6-13, in: NA, Min. Kol., 2.10.36.04, inv. 430, Vb. 25-1-1907, no. 52; Hagenaar, 'Bijlage: Onlusten op Flores in 1904 en 1905, behoort bij Beknopte gegevens betreffende het patrouillegebied van het detachement te Larantoeka omvattende Larantoeka, Maoemere, Adonara, Soloren en Lomblen', pp. 8-9, in: NA, MvO, 2.10.39, Collectie KIT, 1300; Rambonnet to Commandant der Zeemacht te Batavia, 7-8-1904, pp. 2-4, in: NA, Min. Kol., 2.10.36.04, inv. 373, Vb. 21-4-1906, no. 55. 
On 16 August the most prominent leaders of Hinga surrendered, five of whom were immediately arrested and taken on board the Mataram. After payment of the fine of $f 5,000$, the people of Hinga were allowed to rebuild their villages, but not in the easily defendable places where they had stood before and no longer so concentrated as before. Those interned on Lembata were allowed to return. Luli Hada, the legitimate head of Hinga whom for some reason the Dutch deemed to have been driven into the background by lesser leaders and to have been basically peaceful, was restored to his position. The people of Hinga said that the revolt had been supported not only by Kiwangona, but also by Raja Lorenzo, who had provided them with arms, powder and promises. Before departing, the Dutch force arrested arms dealers in Lamahala and Larantuka. The Dutch permanently closed the Semara market. ${ }^{32}$

\section{Background to the Hinga and Kiwangona alliance}

The support given the Paji region Hinga by the Demon region Kiwangona may at first seem odd. Arndt comments that the Demon never united in all regions to make war on the Paji, and the Paji never acted that way against the Demon either. Lera Wulan's (God's) order that the Demon should kill every Paji and the Paji every Demon who fell into their hands, was never so strictly carried out as it sounded. Arndt (1938:11) gives several examples of regional alliances between Paji and Demon: the Paji village Wulubelolong on Solor established relations of friendship with Demon Tanah Boleng in eastern Adonara. In Tanjung Bunga, eastern Flores, there were peace agreements between some Demon and Paji villages. The Demon village of Pamakayo, Solor, and the Paji village of Terong, Adonara, formed an alliance. Arndt (1938:49-50) also specifically cites Kiwangona's help for Hinga as an example of cooperation across the Paji and Demon divide. Of course in this case, Hinga was falling away from the Raja of Adonara.

In fact Juga's depredations in the territory of the Raja of Adonara prior to the Hinga war were already a serious breach of a long-standing relationship between these parties, dating back to a war between Hinga and a village

32 Koloniaal verslag 1905:80; Heckler to governor-general, 12-8-1904, 'Kort verslag omtrent den toestand en de voornaamste gebeurtenissen in de Residentie Timor en Onderhoorigheden over de maand Juli 1904', pp. 22-4, in: NA, Min. Kol., 2.10.36.04, inv. 430, Vb. 25-1-1907, no. 52; Heckler to governor-general, 'Kort verslag omtrent den toestand en de voornaamste gebeurtenissen in de Residentie Timor en Onderhoorigheden over de maand Augustus 1904', pp. 8-13, in: NA, Min. Kol., 2.10.36.04, inv. 373, Vb. 21-4-1906, no. 55; Hagenaar, 'Bijlage: Onlusten op Flores in 1904 en 1905, behoort bij Beknopte gegevens betreffende het patrouillegebied van het detachement te Larantoeka omvattende Larantoeka, Maoemere, Adonara, Soloren en Lomblen', p. 11, in: NA, $\mathrm{MvO}, 2.10 .39$, Collectie KIT, 1300. 
called Libu. Libu no longer exists. It was situated on a rocky outcropping on the southern slopes of Ilé Boleng, not far inland from Pasar Semara. The site is now completely overgrown.

According to Haji Muktar Lebu Kelake Kéi (Haji Muktar Lebu Raya), Libu was a village with no surrounding lands, which was in conflict with Kiwangona under its leader Korek Bima. ${ }^{33}$ The village was surrounded by land belonging to Boleng and Kiwangona. It asked help of the Méo (warriors) from the Amfoan region of Timor. Because it had no land, it had no location nearby to place them; so the Méo had to stay in Wureh, Adonara, where they were surrounded by Korek Bima's troops. Eventually their food gave out, and they had no place to get any more. They turned to the Raja of Adonara to ask for food. As it happens, Korek Bima was in Adonara at the time asking for help against Libu. The Raja of Adonara sat the leader of the Méo down across from Korek Bima and told him this was the man he was trying to make war on. The Raja of Adonara said that he would give the Méo food, if the Méo would switch sides. They agreed to do so, and with their help Korek Bima destroyed Libu.

The survivors of Libu are scattered all over Adonara and beyond, including Larantuka. There are physical remains of Libu, but no inhabitants. Descendants of Libu are prohibited by mystical sanction from entering the old site. In recognition of the help of the (Paji) Raja of Adonara (the Demon), Korek Bima gave him one of the hamlets of Kiwangona named Puhu. Puhu exists today and is half in Demon and half in Paji spheres. The phrase for their position is lewo Demon duiq Pagi, that is to say that their land (village) is Demon, but their money (tribute) is Paji. Arakian Kamba Kéi Helu, son of acting Raja Bapa Ana, said that Kiwangona gave Puhu Onga Belã to Adonara. As Demon territory it continued to be administered from Larantuka, but for adat purposes it belonged to Adonara. The transfer was in recognition of the help Adonara gave Kiwangona in the war against Libu. It is customary after a war for the victors to feed their allies, pau ata nara or pau lewo. Puhu Onga Belã was given so that they could wuaq wayak, give betel, to Adonara; but he said not just to the raja but to everyone in the territory of Adonara, including those from Witihama.

According to Kalesar (n.d.a:36) Libu was located on a hill surrounded by stone thrown up by the volcano Ilé Boleng. Its territory extended to the west and south to the coast. To the west of it were a series of small hamlets which represented its niha karang, its defensive line. Among these hamlets were Riang Kelepok, Riang Kenawa, Riang Puho, Riang Laka, Riang Wato Beta, Lewo Buku, and Lama Aluk. At the shore there were two market places

33 Korek Bima is currently the name of a clan, so the interpretation that Korek Bima in this case was the name of the leader is uncertain, but possible. 
named Pasar Keliha and Pasar Keremek. Pasar Keliha was a market for ordinary goods. Pasar Keremek was a slave market. Libu was well known then as a village of slave traders. It is said that people who went past Libu were frequently caught. Often they were told from the top of lontar palms, 'tomorrow we are going to capture you and sell you to buy fish'. Because Libu was located at a crossroads, people from the interior at Kiwangona who wanted to go to the shore or people from the eastern part of Tanah Boleng who wanted to go to Lamahala or Terong had to go via Libu. Libu, Kalesar writes, was a powerful and courageous village which thus occupied a strategic position.

One version of the destruction of Libu says it occurred when Dura Ola was in power (in Kiwangona). At first Dura Ola was allied with Eko Bunga from Lewobunga (just west of Ilé Woka in south central Adonara). Then Dura Ola and Eko Bunga allied themselves with present-day Narasaosina (in the territory of the Raja of Adonara in south central Adonara). They promised not to attack each other. Around Narasaosina there were seven nobo (stone seats). There were two stone seats for Eko Bunga and Seli from Lewobunga, two further stone seats for Bibo and Gawi Raran from Lewohoko (in the Demon region immediately to the west of the village of Adonara), and two more stone seats for Bisara and Lako Nawa from Wokawolo. As well there was one stone seat, the seventh, which was newly erected later for Dura Ola.

The next step was that Dura and Eko attempted to take the hamlets (subject to Libu) on the side of the hills. Several hamlets submitted except for Lama Aluk. During a festival and dance, Eko Bunga suddenly attacked Lama Aluk. The leader of the dance was shot. As a result the dancers and inhabitants of Lama Aluk fled, each finding his own shelter. These activities of Eko and Dura threatened Libu, which quickly asked help from the Méo. When the Méo arrived from Timor, they went ashore first at the village of Adonara. Adonara had struck an alliance with Kiwangona. The Raja of Adonara told the Méo that Kiwangona was an ally of Adonara, and they were not allowed to attack them. If they needed peanuts and green gram they could get them in Adonara, for there were no peanuts and green gram in Libu. This offer was accepted. The Méo then joined the Raja of Adonara and together with Adonara helped Kiwangona attack and burn Libu. When the inhabitants of Libu fled, they took their sacred stones and paraphernalia representing 'the power of the village', so that they were not able to return.

Kalesar (n.d.a:40) estimates the date of the war against Libu as between 1870 and 1875. The only mention of Libu in the records is a statement that the people of Libu overran Wokawolo, Adonara, in $1864 .^{34}$ The important role played by the Méo does aid in arriving at an approximation of the period in which these events occurred.

34 'Kort verslag omtrent den stand der zaken en het personeel in de residentie Timor gedurende de maand December 1864', in: Arsip Nasional Republik Indonesia (ANRI), Jakarta. 
The Méo were quite active during the middle of the nineteenth century. At an undated time toward the middle of the nineteenth century, Kalikur, the ruling village of Kédang, Lembata, then governed by Sarabiti Lawé, engaged in war with the nearby village of Leu Wohung. Kalikur prevailed after bringing in assistance from the Amfoan, the locally famous Méo, of northwest Timor. ${ }^{35}$ When Raja Begu of Adonara, who was 'respected and feared', was killed in the village on 28 July 1850 by people from Lewohoko, said to have been led by Libu Kaliba, his son Pela requested powder and men from the resident, who promised to supply him so far as possible. Troops from Amfoan and Ambenu, northwest Timor, helped destroy Lewohoko, killing many and taking a great number of prisoners. The resident leaves unstated what role the government had in sending these troops from Timor. ${ }^{36}$ According to Abdul Salam Sarabiti, ruler of Kédang, following the death of Begu, the Kapitan of Adonara, Sarabiti Kotak, turned to Sarabiti Lawé and asked him for help. Sarabiti Lawé's mother came from the same clan Lewo Belung, which now calls itself Sarabiti Waihale, as the kapitan. Sarabiti Lawé then arranged for the Méo to come from Timor. ${ }^{37}$

In December 1856, the head of Belagar Lama on Pantar was attacked by 300 troops requested by the Raja of Bernusa, Pantar, from the Raja of Amfoan. ${ }^{38}$ In

35 Barnes 2001:285-9. Schulte Nordholt (1971:314-6) surveys what little information there is about the district of Amfoan. Suffice it to say that the existing reports are so obscure as to be of little help at present.

36 D.W.C. van Lynden, 'Algemeen verslag der residentie Timor en Onderhoorigheden over het jaar 1850'; D.W.C. van Lynden, 'Algemeen verslag der residentie Timor en Onderhoorigheden over het jaar 1851', in: ANRI.

37 Sarabiti n.d. The grandson of Arakian Kamba through his mother Ema Bunga and of Bapa Dia leader (Kapitan or Rian Baraq) of Kédang, Bapa Tenueng or N.T. Sarabiti, told me concerning this incident that although Raja Begu was dead, he lay with his eyes wide open. The villagers gathered his flesh together and mixed it with ginger, which brought him back to life. However, Kapitan Kotak Kaya told Begu that it was better for him to be dead; if he remained alive, people would say that they were witches. Kotak Kaya then told Begu that they would proceed to search for the cause of his unfortunate death. Then Kotak Kaya asked Begu if the affines from Terong should search for the cause. Begu closed his eyes. He then stated the same question in reference to Boleng Adonara, and Begu again closed his eyes. He continued in this manner until he reached the affines from Kédang, when he opened his eyes. Kotak Kaya called Musa Sarabiti head of Kédang to ask for Méo. Musa Sarabiti was the son of Sarabiti Lawé. Thus there is a discrepancy in these reports, unless as may well be true, Musa Sarabiti provided this service on behalf of his father before succeeding to the Kalikur leadership. Musa Sarabiti went to Sagu to look for the problem. He then returned and brought around two hundred Méo. The Méo burned Lewoko and made war on Kiwangona, where they killed Raja Ronga.

38 'Kort verslag omtrent den stand der zaken en het personeel in de residentie Timor gedurende de maand Augustus 1856', 'Kort verslag omtrent den stand der zaken en het personeel in de residentie Timor gedurende de maand October 1856', in: ANRI; S.G.F. Fraenkel, 'Politiek verslag der residentie Timor over 1856', S.G.F. Fraenkel, 'Politiek verslag der residentie Timor over 1857', in: ANRI. 
1874 the Raja of Adonara, Kamba Begu, asked for help in punishing the people of Lewotolok, Lembata, for piracy on a Butonese ship in 1872. In September 1874, in the presence of Resident H.C. Humme, 600 Méo took 132 heads in Lewotolok. From there, they went on to Kalikur in Kédang, where they helped the rian baraq (ruler) subdue rebellious mountain villages, again with the loss of many heads. ${ }^{39}$ At the end of 1874, with the permission of the resident, 159 Amfoan troops were sent to protect the Raja of Alor in a fight with mountain dwellers. Acting on his own, the raja set out to punish some small villages, in which action the Amfoan troops took a number of heads and captured 27 people. The raja wanted to invite more Amfoan soldiers to punish a larger village, but the resident refused to give permission (Koloniaal verslag 1875:27).

Concerning the Lewotolok incident, Kniphorst (1885:333-4) later exclaimed, 'Is it clear? To punish an incident of piracy, which at the time had already taken place two years before, not only were 132 heads taken, but also many defenceless people were killed and that indeed covered with the Netherlands flag and a government steamship and thereby, naturally, in the eyes of the natives, with the sanction of the Netherlands Indies government!' Resident Humme was removed from office in punishment, even though in his departing report he claimed that the whole expedition with the Amfoan troops had been approved by the government before he took office. ${ }^{40}$

39 Koloniaal verslag 1875:26; Barnes 2001:296-7. The name of the leader of the Méo during their first incursion into Kédang during the war with Leu Wohung is unknown. In the colonial records, there is a mention of Willem Bartholomeus Manek Amfoan in 1854. In 1874, their leader was Raja Welem, the son of Nona Biri who had married the leader of the Méo after the defeat of Leu Wohung and who came from the same clan, Leu Tuang, as Musa Sarabiti, the head of Kédang (Barnes 2001:299). The Raja Muda (that is prince regent) of Amfoan Sorbian in 1876 was named Willem Manoh, described by Resident Ecoma Verstege as the presumed successor of the Raja of Amfoan/Sorbian, who died in 1875. Ecoma Verstege described Willem Manoh as a youth of around 20 years of age who had a good and gentle appearance and who seemed to be liked by the heads of the people of Amfoan. However, he discovered that the raja muda, whom he had earlier regarded as composed and gentle, had just three months before shot two of his subjects dead in cold blood and had another person killed by his Méo. No one could say exactly what the reason for this atrocity was, but ascribed it to the witchcraft practised by the victims. Considering that the earlier Raja of Amfoan/Sorbian, who was constantly under the baleful influence of strong drink, also killed various people in the same way, the resident awaited the decision of the government as to whether the young man should be appointed Raja of Amfoan. Willem Manoh replaced Moloh Manoh as Raja of Amfoan/Sorbian on 14 July 1876. See 'Kort verslag omtrent den stand der zaken en het personeel in de residentie Timor gedurende de maand Juli 1854', in: ANRI; Ecoma Verstege, 'Kort verslag omtrent den stand stand van zaken en het personeel in de Residentie Timor gedurende de maand Mei 1876', in: ANRI; Koloniaal verslag 1875:27; Regeerings-almanak 1878.

40 Humme, 'Memorie van overgave van den afgetreden Resident van Timor en Onderhoorigheden', in: ANRI. Humme goes on to comment that his demand that those responsible for the piracy be turned over had been answered by sending human excrement, provoking the marginal note, 'niet gracieus'. He then wrote that 'it is self-evident that I did not join in the fight and that the Timorese fought the war in their manner and took heads is not my fault. The expedition was not organized by me.' However, his superiors were not moved by these attempts at self-exoneration. See also Riedel 1885:5; Colijn 1907:129; Dietrich 1983:41, 53 note 6, 1989:64, 287 note 5. 


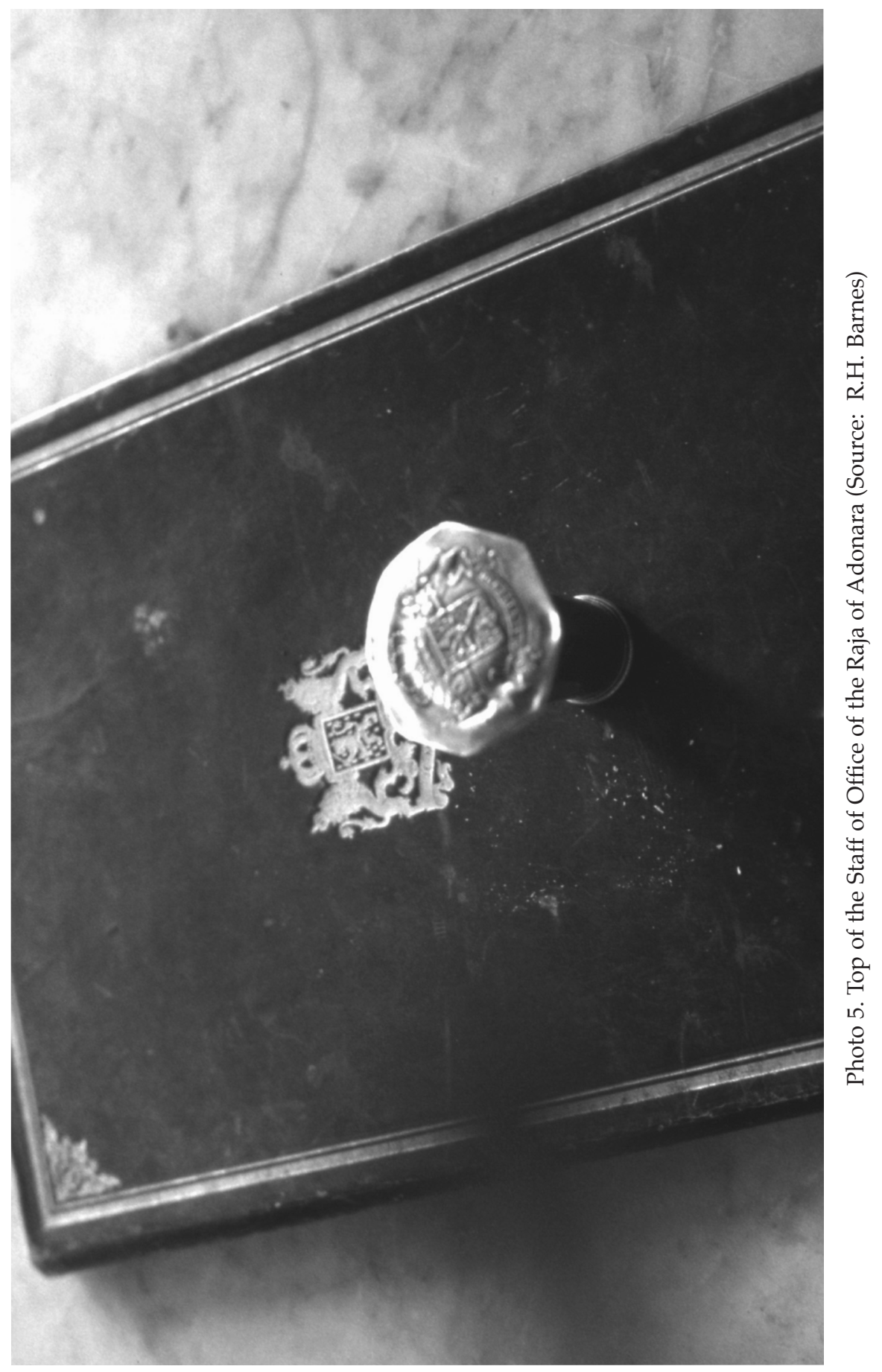


Resident Ecoma Verstege dismissed further requests from the rajas for expeditions such as those using the Amfoan because of the savagery which accompanied them. Above all the government forbade any further use of Timorese auxiliary troops because of their well-known bloodthirstiness and rapacity (Koloniaal verslag 1877:38). Finally, under pressure from District Commissioner Kleian and Resident Riedel to intervene in a dispute between the Baipitu district of eastern Flores and villages of the Paji region of Tanjung Bunga, in May 1880 Raja Dominggo of Larantuka requested the hiring of 1,000 Méo, but was refused (Dietrich 1983:49).

Another indication of the dates of the destruction of Libu can be derived from the activities of a certain Semara, whose name was applied to Pasar Semara and also in the phrase Tanah Semara, in the past sometimes to the region otherwise known as Tanah Boleng (Beckering 1911:173; Kalesar n.d.a:39). Kluppel (1873:396, note) provides the first explicit mention of this personage. He writes that there was one region named Durang in the mountains of Woko (Woka) on Adonara which was an exception to the general rule that mountain people were mostly afraid of Europeans. When he first visited this place in 1867 , he was especially struck by this. While he was in Terong and Lamahala, he wanted to visit Durang because he had heard a lot about the leader Semara. Early in the morning they mounted their horses and reached Durang by footpath by 11:00. Semara received them festively. The most prominent people were present and the women did not run away but invited them in graciously. He was particularly impressed that the people were tidier and the houses were better than elsewhere. Two pigs and a goat were slaughtered and a fine meal was served on blue plates, with white egg cups and old-fashioned beer glasses. From the interpreter he learned that Durang had been settled a hundred years before and that earlier it had been populated by seafarers. He also saw ships' lanterns, a chicken coop, and a cannon mounted on wheels. 'One thing and the other brought me to the conviction that the people were formerly pirates'.

Later the reports on Semara were less favourable. Resident Ecoma Verstege wrote in 1878 that Semara gave reasons for irritation to a few shore villages of the lima pantai because of his savagery and riotous behaviour; but even he had now seen the error of his ways and tried to make good again through a better way of life and to subject himself to his superior the Raja of Larantuka. ${ }^{41}$ In 1880 the savage mountain leader Semara, who for years had been the dread of the population, went to Terong, where the post holder was then stationed, to show to the government his good intentions. In the presence of other leaders he promised to forbid his popula-

41 Ecoma Verstege, 'Memorie van overgave van den aftredenden Resident van Timor en Onderhoorigheden', 1878, in: ANRI. 
tion from hunting heads and making war, and declared himself ready to distribute coffee in his region, for which the necessary plants were given him (Koloniaal verslag 1880:25). In 1882, the Koloniaal verslag reported that Semara had not lived up to his promises (Koloniaal verslag 1882:25). In 1884, the report was that Semara had died and that the resident therefore had hopes of putting a permanent end to disputes between the shore and mountain peoples (Koloniaal verslag 1884:26).

According to Kalesar (n.d.a:40), at some period Semara, who had several wives, wanted to marry Jebe from Libu. His first wife, Ina Palan, and Semara's brothers and sisters did not agree. They told Jebe that she could marry Semara but first must weave a nowin (a cloth for a male) which was as long as from Wokawolo to Wai Nungo. The instructions were impossible to fulfil. Subsequently Jebe was ridiculed and chased away. Jebe fled to Larantuka, where she eventually married. Her son Markus Suban Betan is buried in Waibalun. His gravestone gives his years as 1880 to 1938. Thus it is possible that Jebe's abortive affair with Semara occurred during the period before the destruction of Libu.

Kalesar (n.d.a:39) writes that mission records indicate that for several years before 1883, there were quarrels between Semara of Wokawolo and Kapitan Belae Seraka of Lamahala. Belae Seraka had caused a great deal of trouble in Kédang in the 1860s (Dietrich 1983:45). Later he burned the village of Boleng Adonara in southeast Adonara in 1888. Eventually he surrendered to the Dutch in January 1889 and was banished to Java (Dietrich 1989:66-7; Barnes 2001:293-4). Kalesar (n.d.a:39) makes the extraordinary statement that Holland ordered that Belae Seraka be killed. This order went via the Raja of Larantuka and was then passed on to Semara. So far as I know there is no documentary confirmation of this claim. Finally, Kalesar says very circumstantially that on 27 October 1883, Semara was killed by Eko Buang. Semara was Eko Buang's father's younger brother. Eko Buang frequently stayed in Lamahala with his sister Ina Lelu, who was married to Bapa Isa Suban from Suku Goran clan in Lamahala. Bapa Isa Suban was the younger brother of Belae Seraka, who ordered Eko Buang to kill Semara.

It is said that on the night that he wanted to kill Semara, Eko experienced an internal struggle. Semara was his father [that is, his father's brother]. To kill him meant killing his father. Not killing him meant his life was threatened [by Belae Seraka]. 'Rather than being killed myself it is better that I am the one who kills'. Thereafter he would be greeted as a hero in Lamahala with firing [of shots] three times in his honour. (Kalesar n.d.a:39.)

After Semara was killed, Eko Buang was not arrested nor tried by the Dutch. He eventually died by falling from a lontar palm (in local culture a certain sign of a severe fault provoking the anger of the ancestors). 


\section{District Commissioner Misero}

The district commissioner stationed in Larantuka at the time of the Hinga war was J. Misero. He is said to have been constantly at loggerheads with Raja Lorenzo and a friend of the man with whom the government replaced him, Sinyo Luis. ${ }^{42}$ In fact the Kolonial verslag (1903:104) says that the raja had had as good as no contact with Misero in years. Mission records, according to Steenbrink (2003:176), suggest that the Protestant Eurasian Post Holder of Atapupu, Timor, was transferred to Melolo, Sumba, where there was no Catholic priest, after he and his daughter converted to Catholicism in February 1891. Misero was appointed briefly to replace him as post holder. The mission interpreted the transfer as an anti-Catholic move orchestrated by Resident Hoogkamer, his secretary E.F. Kleian, who had been district commissioner in Larantuka from 1874 to $1885,{ }^{43}$ the Protestant minister J.F. Nix, and Misero. Misero they deemed a vigorous anti-Catholic and an adept of local magic practices. He was soon made district commissioner in Larantuka.

In the tiny Protestant graveyard in Larantuka there are two graves, one of the widow M.L.T.H. Misero who died at the age of 57 on 25 March 1889, and the other of another woman P.H. Misero who died at the age of 30 on 8 July 1889. Misero was officially appointed Post Holder of Solor only on 31 May 1889 and served until 1891, when he was transferred to Atapupu (Regeeringsalmanak 1890, 1891). The dates of his appointment on Solor coincide only approximately with the death dates of his possible relatives in Larantuka, but there could not have been many Protestant women named Misero in Larantuka at the time, and dates of appointment of the various European and non-European officials often did not coincide with when they actually assumed their functions. Misero officially became District Commissioner of Larantuka 24 March 1892, replacing A.T. Worms on that date. ${ }^{44}$ Hagenaar reports that he retired on 29 January 1908 (probably the date of official confirmation), ${ }^{45}$ but Dietrich (1989:77) gives the date as 27 December 1907. In either

\footnotetext{
42 KITLV, Collectie Wertenbroek.

$43 \quad$ His period in the post was broken. The exact dates given by Hagenaar are 30 July 1874 to 13 November 1876 and 20 March 1877 to 6 March 1885. See Hagenaar, 'Bijlage: Onlusten op Flores in 1904 en 1905, behoort bij Beknopte gegevens betreffende het patrouillegebied van het detachement te Larantoeka omvattende Larantoeka, Maoemere, Adonara, Soloren en Lomblen', p. 109, in: NA, MvO, 2.10.39, Collectie KIT, 1300.

44 Hagenaar, 'Bijlage: Onlusten op Flores in 1904 en 1905, behoort bij Beknopte gegevens betreffende het patrouillegebied van het detachement te Larantoeka omvattende Larantoeka, Maoemere, Adonara, Soloren en Lomblen', p. 109, in: NA, MvO, 2.10.39, Collectie KIT, 1300.

45 Hagenaar, 'Bijlage: Onlusten op Flores in 1904 en 1905, behoort bij Beknopte gegevens betreffende het patrouillegebied van het detachement te Larantoeka omvattende Larantoeka, Maoemere, Adonara, Soloren en Lomblen', p. 109, in: NA, MvO, 2.10.39, Collectie KIT, 1300.
} 


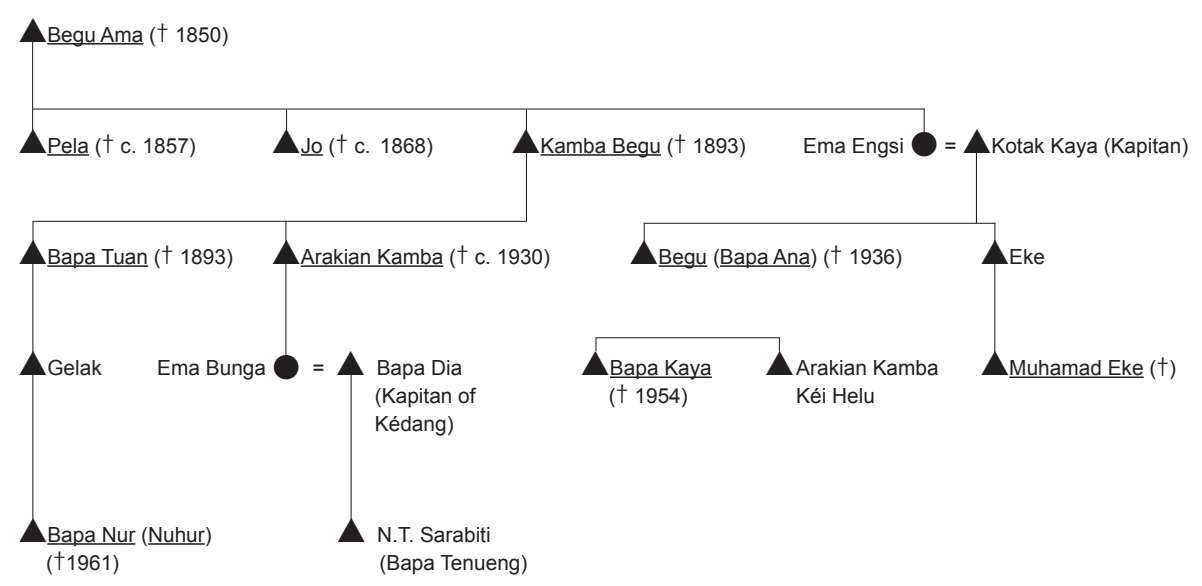

Figure 3. Genealogy of the Rajas of Adonara (the underling indicates that these are the men who were Raja of Adonara)

case he served in Larantuka for sixteen years. Counting his period on Solor, he spent around eighteen years in the region. No other holder of the post between 1851 and 1934 matched his tenure in the region. Only his predecessor Kleian, who was stationed there in two stints totalling about ten years, had comparable experience. Most managed only one or two years, and some did not last a full year. When Misero retired, Resident J.F.A. de Rooy demanded that his replacement be someone with more education and energy. None of his next five successors served for more than a year and a quarter, and the service of two was described as unsatisfactory (Dietrich 1989:77-8).

When the Hinga war was over, fifty men from Koli (Kolilanang, Kolimasang and related villages) in northeast Adonara, which had been fined $f 500$ for not assisting the Raja of Adonara in the war, were taken to Larantuka, where with the Raja of Adonara (no doubt under his supervision) they built a fence around Misero's house (Kalesar n.d.b:29; Koloniaal verslag 1905:79). In July 1904, after Don Lorenzo was deposed, Deputy Commissioner Hellwig consulted with Raja Sinyo Luis of Larantuka and Raja Arakian Kamba of Adonara in order to eliminate the oha beloné ('mat and pillow') wars and the wars between Demon and Paji. The Raja of Adonara wanted them to be permitted, but Misero did not agree. However, Raja Luis also wanted to permit them (Kalesar n.d.b:29).

Arakian Kamba Kéi Helu described Misero to me as a powerful man who was carried about Larantuka and elsewhere by four porters. He married a woman from the clan of the Kapitan of Adonara named Abon, thus a Muslim woman. After Misero retired, he lived in Makassar, where later acting Raja of 
Adonara Bapa Kaya (and a relative of Abon) boarded with him while studying there. ${ }^{46}$ The Dutch regarded Bapa Kaya as better educated than the hereditary future Raja of Adonara Bapa Nur (also Nuhur). Arakian Kamba Kéi Helu, who was born the year Bapa Ana died (1936) and is considerably younger than his elder step-brother Bapa Kaya, spent part of his youth living in the home of Misero's widow in Surabaya. For a simplified chart of the genealogical relationships among the rajas and acting rajas of Adonara, see Figure 3.

In a letter in his own defence, Raja Lorenzo stated that Misero had been reprimanded by Resident C.M.E. Merens (who served 3 March 1893 through 1895) for burning the raja's Dutch flag one evening. Because of that reprimand Misero wished to take revenge on him. Misero had received a woman named Laba Rua from the Raja of Adonara, with whom he already had a son. In fact, I was told, as above, that Misero had married Abon, a relative of the Kapitan of Adonara. Allegedly whenever Misero travelled to Sagu for pleasure, he claimed compensation for an official trip from the resident and also received presents from the Raja of Adonara. Because of this consideration, he protected the Raja of Adonara and repressed the Raja of Larantuka. ${ }^{47}$

In October 1903, Pastor Hoeberechts wrote to Resident Heckler complaining about Misero, who had said that an end must be made with the Raja of Larantuka. Misero was a personal enemy, he claimed, of the Raja of Larantuka. Misero had personally taken down the Netherlands flag, which had been raised in the yard of Raja Lorenzo in honour of the resident at the time, and burned it on the spot. The raja complained to the resident. Misero did not appreciate the ensuing reaction and since that time they, who earlier were friends, were enemies. The Rajas of Adonara and Larantuka were not friendly powers, and a neutral commissioner was required to mediate between them. How could Misero be neutral when he had so many ties to Adonara? Heckler replied with a general and detailed rebuff to Hoeberechts for interfering in government matters, but also sent a rebuke to Misero for speaking out of turn. ${ }^{48}$

$46 \quad$ Koloniaal verslag 1915:46; KITLV, Collectie Wertenbroek.

47 Diaz Vieira Godinho to n.n., c. 1904, p. 5, in: Arsip Regio, Ende, Laan 1962-68:1237-44; Diaz Vieira Godinho to governor-general, c. 1904, p. 2, in: Arsip Regio, Ende, Laan 1962-68:1241.

48 Hoeberechts to Heckler, 9-10-1903, p. 2, in: NA, Min. Kol., 2.10.36.04, inv. 373, Vb. 21-4-1906, no. 55; Heckler to Hoeberechts, 22-10-1903, in: NA, Min. Kol., 2.10.36.04, inv. 373, Vb. 21-4-1906, no. 55; Heckler to Civiel Gezaghebber der Afdeeling Larantoeka en Onderhoorigheden, in: NA, Min. Kol., 2.10.36.04, inv. 373, Vb. 21-4-1906, no. 55. 


\section{Conclusion}

Ricklefs (1981:138) lists among the positive consequences of the Dutch expansion: 'feudal political systems, slavery, widow-burning, internecine wars, headhunting, cannibalism, piracy and other unacceptable practices were being abolished under Dutch rule'. As a statement of finished achievements, this list cannot be accepted for Adonara and environs, although, with the exception of widow-burning and cannibalism which were not relevant, each was a stated aim of the authorities at one time or other, however inconsistently pursued in practice.

As for abolishing feudal systems, the government was interested in replacing what it defined as feudal structures with a bureaucratic hierarchical framework of authority, certainly not with 'one man one vote' democracy. What it was actually struggling to eliminate, however, was a pattern in which legitimate authority and power was divided vertically and horizontally among the most diverse groups (Dietrich 1989:46-7). The government even considered abolishing the office of Raja of Larantuka and for years tried to negotiate the consolidation of the small princedoms of Lohayong, Lamakera, Terong, and Lamahala with that of the Raja of Adonara (Dietrich 1989:78, 164-5). Finally Lohayong in 1929 and Lamakera and Labala on Lembata in 1931 were placed under the Raja of Larantuka, while Terong in 1929 and Lamahala in 1931 were consolidated with Adonara (Van Dijk 1934:709-12; Vatter 1932:32-3). Nevertheless when the Nederlandsch-Indische Civiele Administratie (NICA) government tried to reestablish its control in eastern Indonesia after World War II, it was through the rajas or acting rajas of Flores, including those of Larantuka and Adonara, that it chose to work, thus helping to ensure that these figures would bear the brunt of the anti-feudal policies of the incoming authorities of the Republic of Indonesia after 1949. ${ }^{49}$ A newly unified regency comprising eastern Flores, Adonara, Solor and Lembata under purely civil authority replaced the princedoms on 5 June 1962 (Larantuka dalam angka 1997:1).

World War II, Indonesian independence, and the policies of the post-independence government would necessarily have placed limits on the long-term consequences of events which happened so far in the past as 1904. The Hinga war was not decisive in determining the future shape of local politics, but it did have short-term effects, one of which was to immeasurably strengthen the hand of Raja Arakian Kamba in relation to his own subjects, while at the same time the initiative shifted from the successive Rajas of Larantuka to the government of the residency. No successor to Don Lorenzo had the power

49 Manteiro 1953:1-7, in: Arsip Regio, Ende; Tuhumena-Maspaitella 1954:2-18, in: Arsip San Dominggo, Larantuka. 
or independence of manoeuvre which the resident stripped from him in 1904. Ever since the death of Raja Begu in 1850, the Netherlands authorities had intervened in support of successive Rajas of Adonara: for Begu's son in 1850, for Kamba Begu in suppressing Lewotolok in 1874, for Arakian Kamba in Kédang in 1903, and again in the Hongi Hinga in 1904 (Dietrich 1983:46; Barnes 2001:301-3). From the booty he hauled out of Kédang and from the Hongi Hinga, Arakian Kamba became immensely rich. However, once he died without male offspring, he was followed by a succession of increasingly weakened leaders who were rivals among themselves, and the gain proved not to be lasting. Of the other evils listed by Ricklefs, slavery and piracy were effectively eliminated by the Netherlands Indies government. The repression of internecine wars and headhunting had to await the much worse suppressions of the Soeharto government, but are still not entirely removed from the area (Barnes 2003). Locally the Hongi Hinga is still remembered, there is even a statue to the warriors in Hinga commemorating it, but it has little relevance at present in day-to-day relationships among the descendants of the people who fought on either side.

\section{Acknowledgements}

The information on which this article is based has been gathered over many research trips beginning in 1969, but most derives from research conducted in Witihama, Adonara, between August 2000 and September 2001. That research was supported by grants from the British Academy, the Committee for South East Asian Studies of the British Academy, and the Oppenheimer Fund. The research was carried out under the auspices of the Indonesian Institute of Sciences. I am grateful to all institutions and persons who have, in their manifold ways, supported my research. I am especially grateful to the Arsip Nasional, Jakarta, and Nationaal Archief, The Hague, to Stefan Dietrich for, among many other things, supplying the letters by Raja Lorenzo and Heckler and Onlusten 1907, to Mr D.P. Tick for the photograph of Raja Arakian Kamba. I also wish to thank Arend de Roever for providing photographs 1 through 3 . 
References

Unpublished sources

Arsip Nasional Republik Indonesia, Jakarta

Ecoma Verstege, L.M.G.A.M.

$1876 \quad$ Kort-verslag omtrent den stand van zaken en het personeel in de Residentie Timor gedurende de maand Mei 1876.

1878 Memorie van Overgave van den aftredenden Resident van Timor en Onderhoorigheden.

Fraenkel, S.G.F.

1856 Politiek verslag der Residentie Timor over 1856.

1858 Politiek verslag der Residentie Timor over 1857.

Humme, H.C.

1875 Memorie van overgave van den afgetreden Resident van Timor en Onderhoorigheden.

Kort Verslag

$1854 \quad$ Kort verslag omtrent den stand der zaken en het personeel in de residentie Timor gedurende de maand juli 1854 .

1856a Kort verslag omtrent den stand der zaken en het personeel in de residentie Timor gedurende de maand augustus 1856.

1856b Kort verslag omtrent den stand der zaken en het personeel in de residentie Timor gedurende de maand oktober 1856.

1864 Kort verslag omtrent den stand der zaken en het personeel in de residentie Timor gedurende de maand december 1864 .

Lynden, D.W.C. van

$1850 \quad$ Algemeen verslag der residentie Timor en Onderhoorigheden over het jaar 1850.

1851 Algemeen verslag der residentie Timor en Onderhoorigheden over het jaar 1851.

Rambonnet, J.J.

1904

Commandant J.J. Rambonnet to Commandant der Zeemacht te Batavia, 7 August 1904.

Arsip Regio, Ende

Laan, Petrus

1962-68 Larantuka 1860-1918; Drie jaren missie-werk door twee wereldheren;

Missiewerk door de Jesuieten en door de missionarissen van Steyl.

Nine vols.

Manteiro, L.E.

1953 Perkembangan Flores Sesudah Perang Dunia Ke II. Ende, 12 May 1953. 
Arsip San Dominggo, Larantuka

Tuhumena-Maspaitella, J.B.

1954 Memorie sementara mengenai Flores Timur dan Kepulauan Solor. Larantuka, Flores, Indonesia, 25 March 1954.

Koninklijk Instituut voor Taal-, Land-en Volkenkunde, Leiden

Collectie M.J.H. Wertenbroek, H 1341

Nationaal Archief, The Hague

Collectie C.C.F.M. le Roux, nummer toegang 2.21.097.02

Inventaris Ministerie van Koloniën, 1900-1963; Openbaar verbaal, 1900-1952, nummer toegang 2.10.36.04

Inventaris Memories van Overgave 1849-1962, nummer toegang 2.10.39

Published sources

Arndt, Paul

1938

'Demon und Padzi, die feindichen Brüder des Solor-Archipels', Anthropos 381-58.

B., $\mathrm{H}$.

1905

‘Onlusten op Flores in 1904 en 1905', Indisch Militair Tijdschrift 36:97194.

B., M.

1900

'Flores-Larantuka; Uit een brief der Eerwaarde Zuster M.B. aan de Algemeene Overste te Heijthuizen', Berichten uit Nederlandsch OostIndië voor de Leden van den Sint-Claverbond 22-5:52-59.

Barnes, R.H.

1987

'Avarice and iniquity at the Solor fort', Bijdragen tot de Taal-, Land-en Volkenkunde 143:208-36.

2001 'Alliance and warfare in an eastern Indonesian principality; Kédang in the last half of the nineteenth century', Bijdragen tot de Taal-, Land-en Volkenkunde 157:271-311.

2003 'Fransiskus/Usman Buang Duran; Catholic, Muslim, Communist', Bijdragen tot de Taal, Land- en Volkenkunde 159:1-29.

Beckering, J.D.H.

1911 'Beschrijving der eilanden Adonara en Lomblem, behoorende tot de Solor-Groep', Tijdschrift van het Koninklijk Nederlandsch Aardrijkskundig Genootschap 28(Tweede Serie):167-202.

Bijblad

1857-1948 Bijblad op het Staatsblad van Nederlandsch Indië. Batavia: n.n.

Colijn, H.

1907

Politiek beleid en bestuurszorg in de buitenbezittingen. Eerste gedeelte. Hoofdstuk I en II: Historische inleiding. Batavia: Landsdrukkerij.

Dietrich, Stefan

1983

'Flores in the nineteenth century; Aspects of Dutch colonialism on a non-profitable island', Indonesia Circle 31:39-58. 
Kolonialismus und Mission auf Flores (ca. 1900-1942). Hohenschäftlarn: Renner. [Münchener Beiträge zur Süd-Südostasienkunde 1.]

1997 Kota Rénya, 'Die Stadt der Köningin'; Religion, Identität und Wandel in einer ostindonesischen Kleinstadt. [Habilitationsschrift Universität München.]

Dijk, L.J. van

1934

'De zelfbesturende landschappen in de Residentie Timor en Onderhoorigheden', Indische Gids 56, II:708-12.

Eerde, J.C. van

1923 'Don Lorenzo II van Larantoeka', Onze Eeuw 23-2:73-113.

Gonggrijp, G.F.E.

1934 Geïllustreerde encyclopaedie van Nederlandsch-Indië. Leiden: Leidsche Uitgeversmaatschappij.

Heslinga, T.

1891

'Larantoeka op het eiland Flores; Ter nagedachtenis van den Eerw. Pastoor Corn. ten Brink; Zijn werkkring op het eiland Flores. Berichten uit Nederlandsch Oost-Indië voor de Leden van den Sint-Claverband 3:46-84.

Kalesar, Carolus

n.d.a Catatan tentang peristiwa Libu dan perang Hongi [Manuscript.]

n.d.b Achir masalah Kiwangona dan perang Hongi. [Manuscript.]

Kluppel, J.M.

1873

'De Solor-eilanden', Tijdschrift voor Indische Taal-, Land- en Volkenkunde (TBG) 20:378-98.

Kniphorst, J.H.P.E.

1885 'Een terugblijk op Timor en onderhoorigheden', Tijdschrift voor Nederlandsch Indië 14-2:321-62.

Koloniaal verslag

1868-1924 Koloniaal verslag 1866-1923. 's-Gravenhage: Algemeene Landsdrukkerij. Larantuka dalam angka

1997

Kecamatan Larantuka dalam angka 1996. Larantuka: Badan Pusat Statistik Flores Timur, Propinsi Nusa Tenggara Timur.

Lulofs, C.

1911 'Toepassing en resultaten van de nieuwere beginselen van politiek beleid in de Residentie Timor en Onderhoorigheden', Tijdschrift voor het Binnenlandsch Bestuur 40:281-308.

Onlusten

1907 'De onlusten op Flores', Weekblad voor Indië 4-4:368-73.

Regeerings-almanak

1865-1942 Regeerings-almanak voor Nederlandsch-Indië. Batavia: Landsdrukkerij.

Reid, Anthony

1969

The contest for North Sumatra; Atjeh, the Netherlands and Britain 18581898. Kuala Lumpur: Oxford University Press/University of Malaya Press.

Resink, G.J.

1968

'The all-but-inverted image', in: G.J. Resink, Indonesia's history between the myths; Essays in legal history and historical theory, pp. 325-48. The Hague: Van Hoeve. [Selected Studies on Indonesia 7.] 
Ricklefs, M.C.

$1981 \quad$ A history of modern Indonesia: c. 1300 to the present. London: Macmillan.

Riedel, J.G.F.

1885

'Timor en Onderhoorigheden in 1878 en later', Indisch Gids 7, I:1-12.

Sá, Artur Basílio de (ed.)

1956 História de Maluco no tempo de Gonçalo Pereira Marramaque e Sancho de Vascincellos...1636. Fundação das Primeiras Cristandades nas Ilhas de Solor e Timor, 1624-25. Lisbon: Agência Geral do Ultramar. [Documentação para a História das Missões do Pradroada Português do Oriente, Insulíndia 4.]

Santa Catarina, Lucas de

1733 Quarta parte da historia de S. Domingos. Lisbon: Academia Real.

Sarabiti, Abdul Salam

n.d. Nenek Sarabiti Lawe di Zaman Purbakala. [Manuscript.]

Schmidgall-Tellings, A. Ed. and Alan M. Stevens

1981 Contemporary Indonesian-English dictionary. Chicago: Ohio University Press.

Schulte Nordholt, H.G.

1971 The political system of the Atoni of Timor. The Hague: Nijhoff. [KITLV, Verhandelingen 60.]

Staatsblad

1816-1948 Staatsblad van Nederlandsch Indië. Batavia: Landsdrukkerij.

Steenbrink, Karel

$2003 \quad$ Catholics in Indonesia 1808-1942; A documented history. Volume 1: A modest recovery 1808-1903. Leiden: KITLV Press. [Verhandelingen 196.]

Vatter, Ernst

1932

Ata Kiwan; Unbekannte Berguölker im tropischen Holland: Ein Reisebericht. Leipzig: Bibliographisches Institut.

Verbeek, W.

Politiek beleid en bestuurszorg in de buitenbezittingen. Tweede gedeelte A. Hoofdstuk III: Historisch overzicht 1899-1908. Batavia: Landsdrukkerij. 